\title{
EL MONUMENTO FUNERARIO ROMANO DE LA TORRE DE SANT JOSEP DE VILLAJOYOSA (ALICANTE). NUEVOS DATOS Y PROPUESTA DE RESTITUCIÓN ${ }^{1}$
}

\author{
THE ROMAN FUNERARY MONUMENT TOWER OF SANT JOSEP DE VILLAJOYOSA (ALICANTE). \\ NEW DATA AND PROPOSAL OF RESTITUTION
}

\author{
DIEGO RUIZ-ALCALDE \\ Museo Municipal de Villajoyosa
}

ANA MARÍA CHARQUERO BALLESTER

La Torre de Sant Josep se encuentra situada en el valle que conforma la desembocadura del río Torres, a $150 \mathrm{~m}$ de la línea de $\operatorname{costa}^{2}$, en el actual municipio de Villajoyosa (Fig. 1). Se trata de un sepulcro turriforme romano fechado en el segundo tercio del siglo II d.C. que ha sido descrito y documentado en numerosas ocasiones desde principios del siglo XVII.

Sin embargo, su estudio detallado tuvo que esperar hasta los años 80, cuando L. Abad y M. Bendala llevaron a cabo un amplio estudio comparativo con otros edificios funerarios similares y propusieron una reconstrucción hipotética del monumento.

Dado que Abad y Bendala ya profundizaron ampliamente en esos aspectos, el contenido de este artículo se centrará sobre todo en las siguientes cuestiones: presentar los resultados de las intervenciones

1. Para este artículo hemos contado con la supervisión y colaboración de los dos autores que realizaron el primer estudio exhaustivo del monumento, Lorenzo Abad, Catedrático de Arqueología de la Universidad de Alicante y Manuel Bendala, Catedrático de Arqueología de la Universidad Autónoma de Madrid. Por ello, queremos agradecer a Lorenzo Abad su continuo y para nosotros inestimable asesoramiento sin el cual este trabajo no habría sido posible y a Manuel Bendala, sus valiosas aportaciones acerca de algunos aspectos de esta investigación.

Asimismo, hemos de destacar que muchos de los datos arqueológicos que aquí presentamos proceden de las intervenciones arqueológicas realizadas dentro del Proyecto «Villajoyosa romana: De la República a la Antigüedad Tardía», dirigido por Lorenzo Abad, Antonio Espinosa (Jefe de la Sección de Arqueología Etnología y Museos de Villajoyosa y Profesor asociado de la UA), Sonia Gutiérrez (Catedrática de Arqueología de la UA), Ignacio Grau (Profesor Titular de la UA), Amanda Marcos (Arqueóloga municipal de Villajoyosa) y Diego Ruiz (Arqueólogo municipal de Villajoyosa y coautor de este artículo).

2. Inventariado como bien inmueble número 10 del Catálogo de Bienes y Espacios Protegidos de Villajoyosa, con la categoría de Monumento Bien de Interés Cultural $\left(\mathrm{N}^{\circ}\right.$ de registro del Ministerio 03,31,139-004). arqueológicas realizadas en el monumento en los años 2006, 2008 y los primeros resultados de la campaña actualmente en curso (2012-2013); mostrar los datos del reciente estudio métrico y fotogramétrico realizado en la torre funeraria y en sus restos arquitectónicos dispersos en las inmediaciones; y reinterpretar la reconstrucción hipotética de Abad y Bendala a partir de la perspectiva aportada por el trabajo métrico de campo y la documentación obtenida de las últimas excavaciones. Estas nuevas aportaciones se contrastarán con otros monumentos funerarios principalmente hispanos que avalarán la verosimilitud de nuestras propuestas.

\section{HISTORIA DE LAS INVESTIGACIONES}

La primera noticia con la que contamos es la descripción que Gaspar Escolano hace en 1610 sobre el monumento (Escolano, 1610). Hasta dos siglos después -entre 1780 y 1805 - no aparecerán las descripciones y los dibujos del erudito valenciano Antonio de Valcárcel, Conde de Lumiares, y las del viajero francés Alexandre de Laborde (1806), que además realizó un grabado, de gran valor informativo aún hoy (Fig. 2). Ambos encontraron el monumento incompleto y ya con el nombre con el que se le conoce en la actualidad de Torre de Sant Josep (Abad, 2011, 199-202) ${ }^{3}$.

Sólo dos décadas después, concretamente en 1832, Juan Agustín Ceán Bermúdez publicó también unas notas sobre el monumento en las que menciona que:

«Se descubrieron parte de un acueducto, pedazos de mármol, restos de pavimentos teselatos y de mosaicos, capiteles de columnas, muchas piedras labradas, fragmentos de estatuas, infinitas medallas, y lápidas con inscripciones, de las cuales unas se rompieron y otras se colocaron en Villajoyosa. En las excavaciones

3. En esta publicación aparecen las transcripciones de los estudios realizados por Gaspar Escolano, Antonio Valcárcel y Alexandre de Laborde. 


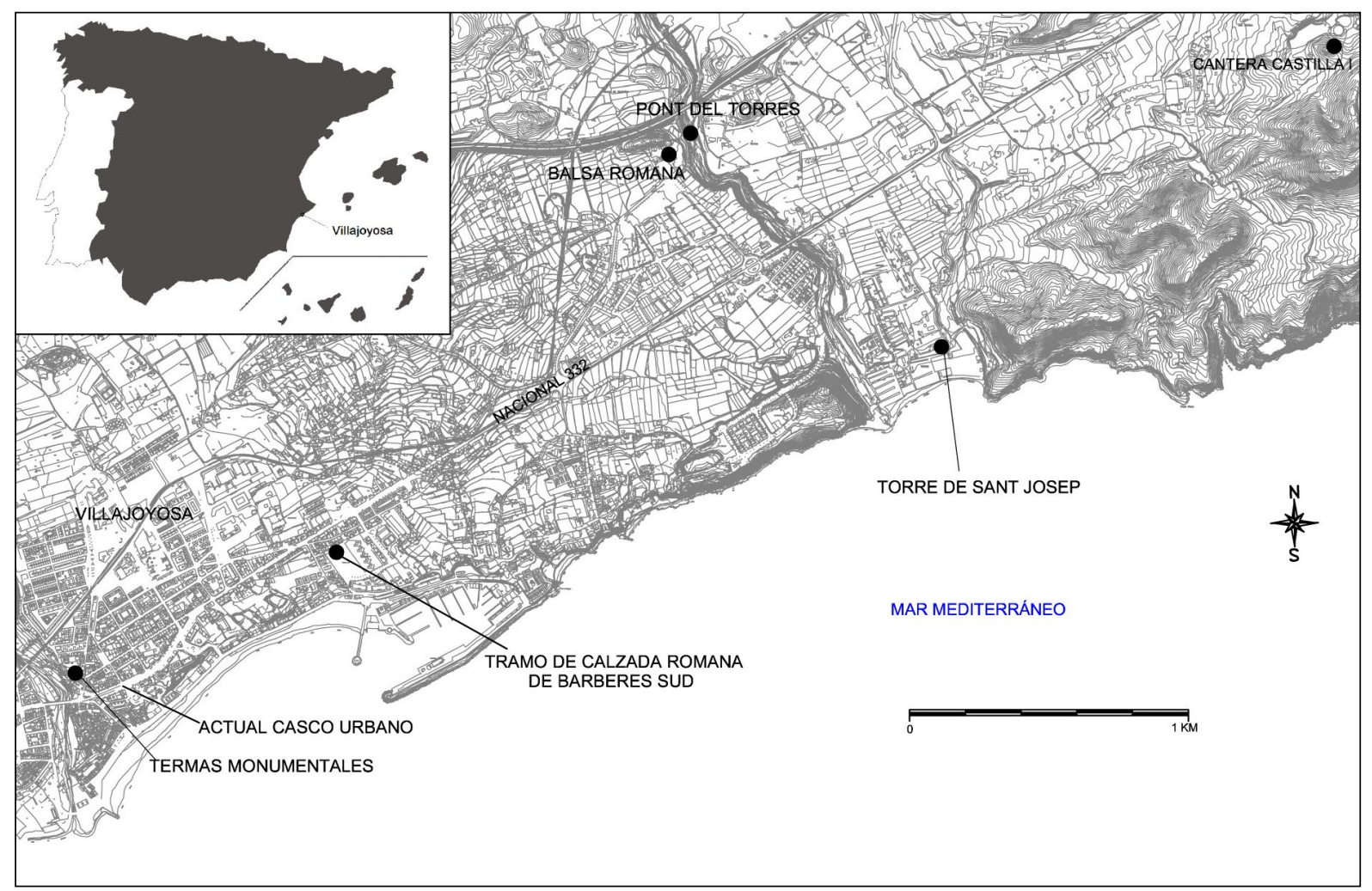

Figura 1: Plano de situación del monumento.

que se hicieron después se desenterraron dos sepulcros, urnas cinerarias, un vaso lacrimatorio, una taza de barro rojo saguntino ${ }^{4}$, una piedra de mármol con dos agujeros, en que estaban las asas, y parecía haber sido una pesa de las que usaban los romanos» (Ceán Bermúdez, 1832, 124 y 125).

A finales del siglo XIX, tenemos otra referencia de una visita que realiza el historiador Ignacio Martí Miquel, concretamente en julio del año 1882, en la que señala la existencia de una noria en estos terrenos:

«... visitamos detenidamente estas ruinas en una tarde del mes de julio del año 1882 (...) Sobre estas ruinas, sembradas aún de infinidad de piedras labradas y otros restos (...) que desde tiempos antiguos se descubren en dichos contornos, y en particular al lado de la noria de la finca, vimos muchas de estas piedras labradas y fragmentos de columnas y capiteles, pero no pudimos encontrar inscripción alguna» (Martí Miquel, en preparación).

A partir de ese momento los estudios sobre el monumento quedaron detenidos y la torre pasó desapercibida hasta principios de los años 80 , cuando los profesores L. Abad de la Universidad de Alicante y

4. Alude a la terra sigillata; Antonio Valcárcel escribió un libro sobre los Barros Saguntinos que fue una obra pionera en su tiempo, pues supuso el primer intento de ordenar un tipo de material, la terra sigillata, que aparecía repetidamente en las excavaciones de los enclaves romanos (Abascal, Die y Cebrián, 2009, 93).
M. Bendala de la Universidad Autónoma de Madrid decidieron buscar el monumento que únicamente conocían por la bibliografía. Encontraron la torre dentro del terreno de un camping -el desaparecido camping de Hércules- al lado de la carretera N-332, a pocos kilómetros de Villajoyosa. La torre formaba parte de una de las instalaciones del camping -un restaurante- que la ocultaba parcialmente.

L. Abad y M. Bendala (1985) llevaron a cabo un levantamiento gráfico del monumento, con dibujos de las fachadas, plantas y secciones, así como de los principales elementos y detalles arquitectónicos. Ello les permitió realizar el estudio formal y funcional del monumento, relacionarlo con otros similares del ámbito mediterráneo y presentar una propuesta hipotética de reconstrucción. La conclusión fue que se trataba de un edificio turriforme de un solo cuerpo, en la línea de los monumentos con edícula cerrada definidos por Kovacsovics (1983).

A pesar de que la torre tenía adosados edificios de cronología posterior, pudieron observar y documentar la cimentación de opus caementicium y el interior de la cámara, cubierto por la bóveda. Para reconstruir la parte superior de la torre usaron como guía dos fragmentos de sillares moldurados, concretamente un fragmento de arquitrabe y otro de cornisa, conservados en las inmediaciones y que probablemente formaron parte de su entablamento.

Para el remate del edificio se decantaron por una pirámide de lados lisos, basándose en la solidez de la base del monumento, en la fortaleza de la bóveda de 


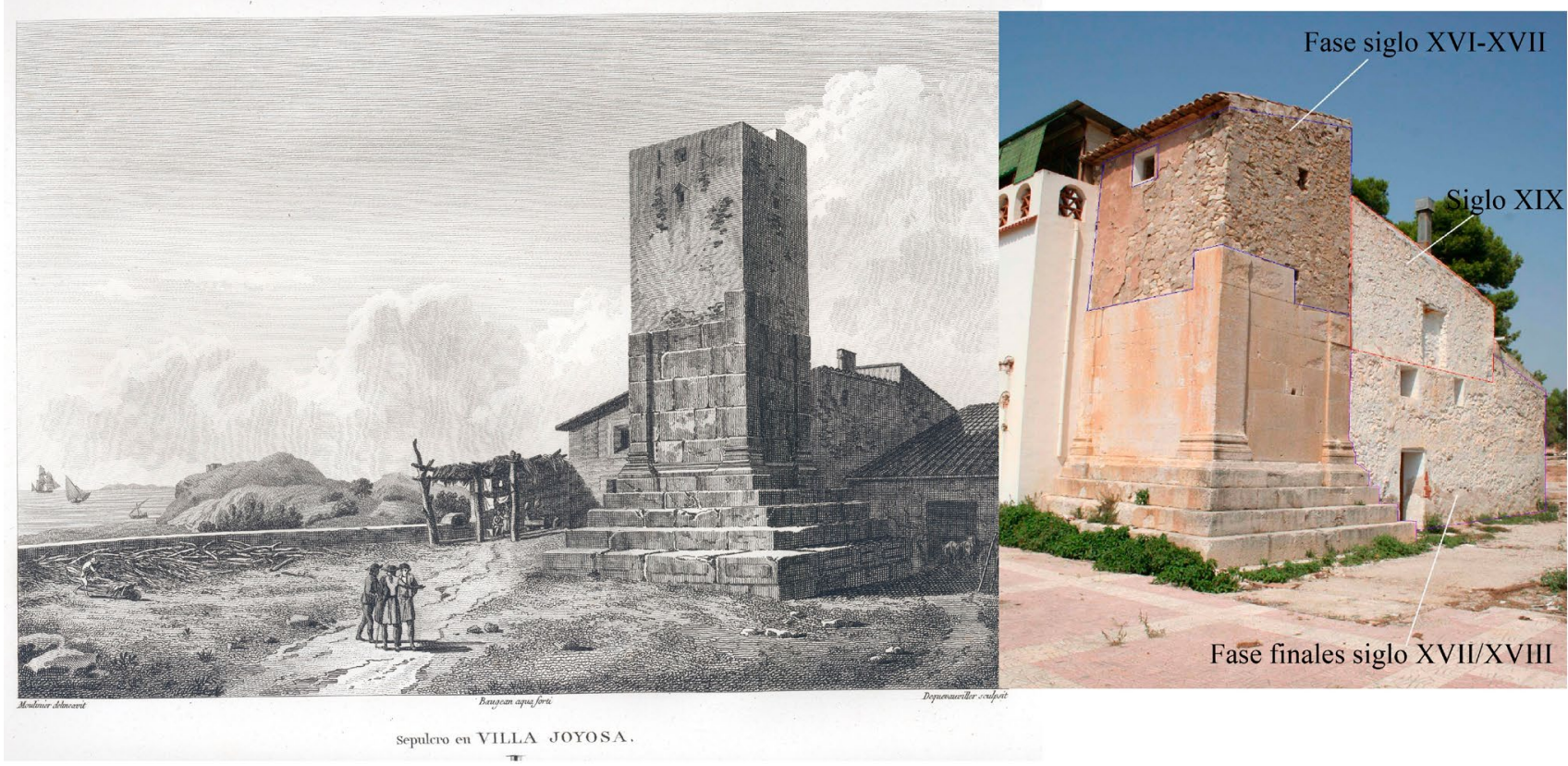

Figura 2: A la izquierda, grabado de Laborde (1806) donde ya se aprecian las fases constructivas de los edificios adyacentes posteriormente documentadas en el estudio de los paramentos realizado en el 2006 (imagen derecha).

cañón y en paralelos de torres similares en el norte de África y en Europa. Aunque, al no haber vestigios de esta posible pirámide, precisaron que se trataba únicamente de un remate hipotético. Finalmente, hicieron hincapié en el rebaje que presentaba en una de sus caras uno de los sillares no moldurados de los alrededores, proponiendo que éste pudo estar destinado a alojar una placa con inscripción.

Esta propuesta de reconstrucción, que fue publicada en 1985 (Abad y Bendala, 1985), sirvió de base para un proyecto de intervención desarrollado en la Conselleria de Cultura de la Generalitat Valenciana y redactado por el arquitecto Carlos Salvadores, que realizó una maqueta con una reconstrucción parcial. En este proyecto se proponía desmontar los edificios anexos y el recrecido del monumento de fases posteriores, conservando la estructura de la torre en su estado original, para posteriormente recrecer uno de sus lados con los elementos originales que habían identificado Abad y Bendala. Sin embargo, los propietarios en ese momento de la torre no accedieron a segregar la propiedad.

En el año 2000 el arquitecto Santiago Varela realizó otra propuesta de intervención que optaba por sellar el monumento con una cubierta plana y neutra (Varela, 2000).

Posteriormente, en el año 2006, dentro del marco de la obra de urbanización del Plan Parcial 27 que ocupaba aproximadamente unos $300.000 \mathrm{~m}^{2}$ de los alrededores de la torre, se llevó a cabo la demolición de las estructuras anexas al monumento tras un estudio parietal de las mismas. La torre, junto con un perímetro aproximado de $25 \mathrm{~m}$ a su alrededor, pasó a ser de propiedad municipal. Asimismo, se llevaron a cabo un total de 3 kilómetros lineales de zanjas de sondeos en los viales del Plan Parcial, cuyos resultados fueron negativos, salvo una pequeña zona industrial del siglo III/IV d.C. al sur de la torre. Todo ello permitió constatar que se trataba de un monumento aislado, que posiblemente estaría relacionado con alguna instalación residencial y con una vía de comunicación marítima, datos a los que aludiremos más adelante en detalle.

Más recientemente entre los años 2008 y 2013, la Sección Municipal de Arqueología de Villajoyosa, en colaboración con la Universidad de Alicante, ha realizado una serie de intervenciones arqueológicas en la torre y su entorno en el marco de un proyecto denominado «Villajoyosa romana: de la República a la Antigüedad Tardía» ${ }^{5}$ (Espinosa, Ruiz-Alcalde y Marcos, 2010).

\section{RESULTADOS DE LA CAMPAÑA DE EXCA- VACIÓN 2008 Y PRIMEROS RESULTADOS DE LA CAMPAÑA 2012/2013}

Las campañas realizadas durante estos años han estado destinadas a cumplir tres objetivos principales.

El primero era contrastar la existencia de las estructuras anexas a la torre visibles en el grabado de Alexandre de Laborde de 1806, y que en parte habían sido documentadas durante los trabajos de arqueología parietal realizados en 2006. En esta nueva intervención se comprobó que algunos muros de época moderna conservaron parte de su alzado tras las obras de

5. Proyecto codirigido por Lorenzo Abad, Antonio Espinosa, Sonia Gutiérrez, Ignacio Grau, Diego Ruiz y Amanda Marcos. 


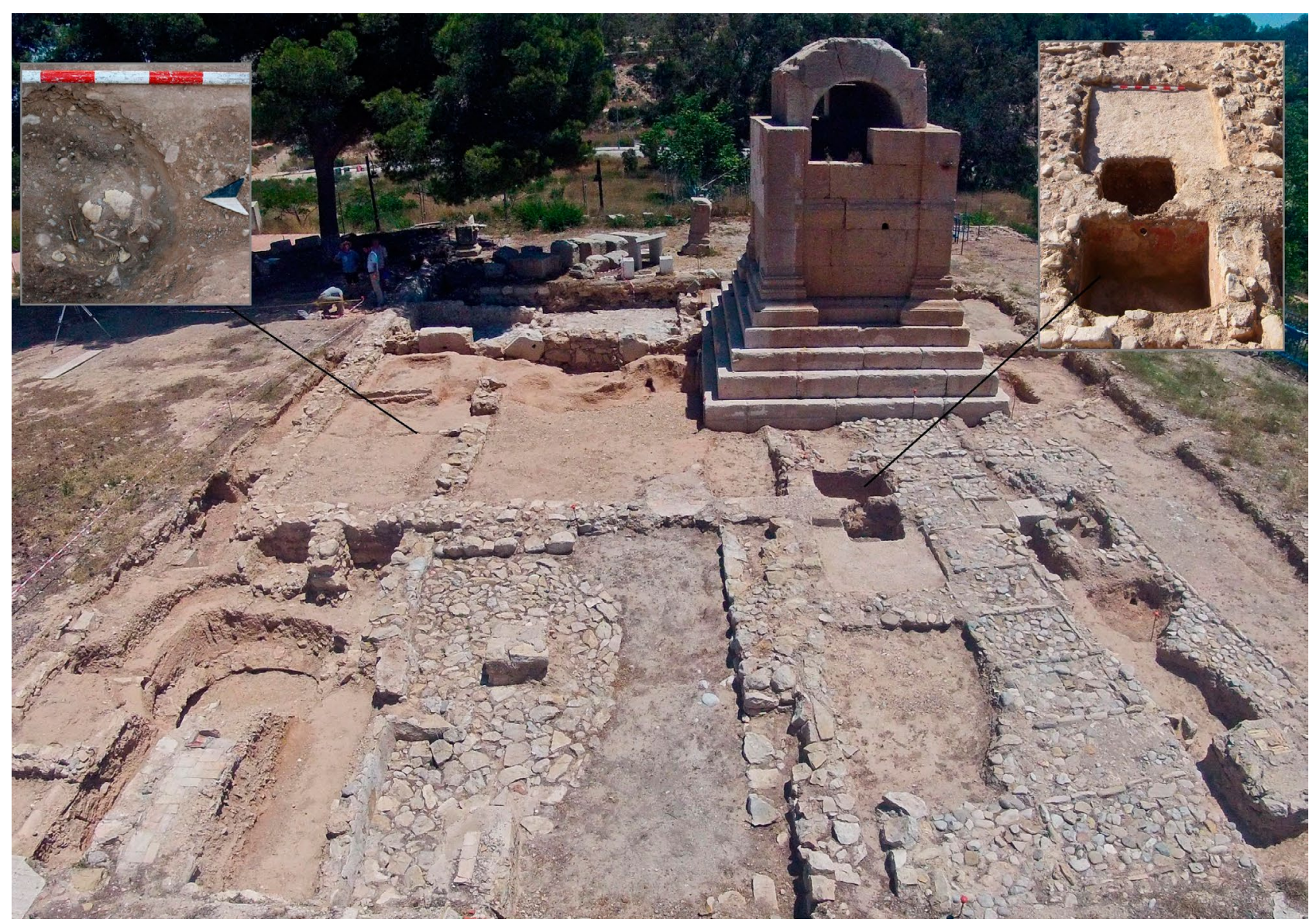

Figura 3: Vista general de la excavación en torno al monumento. En detalle enterramiento infantil y balsas de finales del XVII/XVIII.

reforma de las instalaciones del camping realizadas en 1969 (Fig. 2).

El segundo, excavar el interior del monumento con el fin de comprobar si quedaban restos de la sepultura y a su vez sacar a la luz los cuatro flancos de la torre para documentar su cimentación.

Y el tercero y último, determinar si existían restos coetáneos al monumento bajo las edificaciones de época moderna al pie de la Torre.

Las diferentes campañas de excavación han permitido alcanzar los objetivos propuestos. Hasta el momento, en cuanto a fases de ocupación de época moderna, se han podido documentar los restos de una vivienda construida a finales del siglo XVII / XVIII junto con dos pequeñas balsas de decantación coetáneas a la misma. La vivienda estuvo en funcionamiento hasta entrado el siglo XX, sufriendo numerosas reformas; la más significativa tuvo lugar en la segunda mitad del siglo XIX, momento en el que se pavimenta el porche de entrada mediante cantos rodados (Fig. 3). Hay que destacar que uno de los muros del inmueble presentaba un total de cuatro sillares de época romana reutilizados en su cimentación, dos de los cuales se han podido identificar como parte de la cornisa del monumento (sillares $\mathrm{n}^{\circ} 22 \mathrm{y} \mathrm{n}^{\circ} 24$ ) (Fig. 4).

Asimismo, hemos podido establecer la correlación de las fases documentadas en la excavación, tanto con los grabados de Alexandre de Laborde como con el estudio que se hizo en 2006 de los paramentos conservados en alzado (Fig. 2).

Parte del segundo objetivo consistía en la excavación del interior del monumento; la intervención realizada permitió documentar un primer nivel de expolio (Fosa 2) llevado a cabo entre los siglos XIV y XVII ${ }^{6}$; en este momento se cortó uno de los sillares de la cara norte del monumento, lo que permitió el acceso y su acondicionamiento como área de almacenaje. Asimismo, pensamos que sería entonces cuando se realizó el recrecido superior de la torre que aparece en el grabado de Alexandre de Laborde (Fig. 2). Quedó documentado también un segundo momento de expolio (fosa 1), llevado a cabo en el último cuarto del siglo $\mathrm{XIX}^{7}$, que destruyó cualquier vestigio de la fosa o estructura que acogiera al difunto (Fig. 5).

Estos episodios de expolio han hecho que los restos localizados que se pueden adscribir a época romana

6. En los rellenos de esta zanja de expolio destaca la localización de numerosos fragmentos de cántaro con decoración en manganeso.

7. La datación se fijó sobre todo por la presencia de una moneda de 10 céntimos de Alfonso XII (1878) en uno de los rellenos de la fosa. 


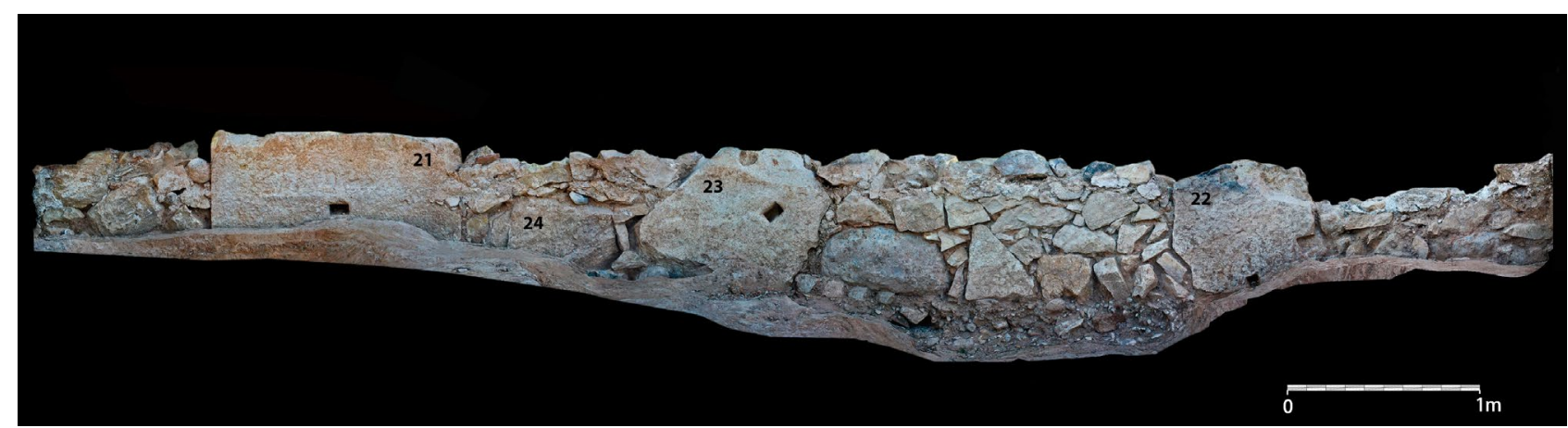

Figura 4: Ortofoto del alzado oeste del muro de cierre oriental de la casa de finales del siglo XVII / XVIII con sillares romanos reutilizados. Los sillares $\mathrm{n}^{\mathrm{o}} 22$ y 24 pertenecen a la cornisa del monumento.

sean escasos; destacan 3 piezas dentales humanas, un fragmento de pasta vítrea (Fig. 6) y una pieza moldurada de la cornisa del monumento de la que hablaremos en el apartado de propuesta de restitución (fragmento de sillar $n^{\circ} 25$, Figs. 15 y 17).

El análisis antropológico de las piezas dentales exhumadas ${ }^{8}$ ha determinado que se trata de dos premolares inferiores y un incisivo inferior de adulto. Dichas piezas no necesariamente tendrían que pertenecer a los restos del finado, ya que se encontraron en los rellenos de colmatación de ambas zanjas de expolio. Sin embargo, su presencia es significativa y nos parece plausible considerar que se trate de restos arrasados del difunto.

Si partimos de esta hipótesis debemos destacar que las tres piezas dentales no presentan muestras de exposición al fuego, hecho que nos llevaría a pensar que nos encontramos ante un ritual de inhumación.

Los últimos datos sobre el ritual funerario empleado en Hispania desde el siglo II a.C. al II d.C. vienen corroborando la idea de una presencia de inhumaciones mucho mayor de la que se pensaba para estos periodos (Abad, 2003, 97). En Hispania conviven rituales de cremación e inhumación desde el mismo inicio de la dominación de Roma, hecho favorecido sin duda por la llegada de gentes del centro o sur de Italia, que venían inhumando desde siglos atrás y que trajeron consigo sus particulares hábitos funerarios (Vaquerizo, 2010, 280). Las cremaciones perduran habitualmente hasta bien entrado el siglo III d.C. momento a partir del cual se generaliza el ritual inhumatorio, tanto en el ámbito urbano como en el rural (Vaquerizo, 2010, 283).

Nuestra sepultura, fechada en el segundo tercio del siglo II d.C. parece estar en consonancia con estos datos. En estas fechas, el ritual de inhumación se atestigua, por ejemplo, en los denominados «Bodegones», tumbas de cámara subterránea con arcosolia de

8. Queremos agradecer los datos aportados al estudio de las piezas dentales a Alejandro Romero, del Departamento de Biotecnología de la Universidad de Alicante, y la ayuda prestada por Milagros Galán, odontóloga. la necrópolis suroriental de Mérida, que se datan en el siglo II d.C. (Bendala, 2004, 87-88). Aunque, en la mayor parte de los monumentos funerarios hispanos en los que se ha podido documentar, el rito empleado es el de cremación. Así ocurre en la Torre sepulcral d'Aiguaviva (Sanmartí, 1984, 129), en la Torre del Cincho en Basilippo (Rodríguez Hidalgo, 1979-80, 429), en el Monumento de cuerpos superpuestos de Edeta (Edificio 2) (González Villaescusa, 2001, 199-201), en los Edificios 1 y 2 de la excavación realizada en la calle Almendralejo $\mathrm{n}^{\circ} 41$ de Badajoz (Augusta Emerita) (Heras y Olmedo, 2010, 47-49), en la Torre Ciega de Cartagena, donde por noticias orales acerca de la existencia de cenizas en su interior se presupone el uso del rito de cremación (Abad, 2003, 93) o en la Tumba monumental de Segobriga que en este caso es del tipo mausoleo en forma de altar (Cebrián, 2010, 141).

En cuanto al fragmento de pasta vítrea antes mencionado, es la única pieza que podría haber pertenecido al ajuar del difunto de entre los elementos encontrados durante la excavación del conditorium. Se trata de un fragmento semiesférico, muy mal conservado, de color azul verdoso y probable adscripción romana, que contrasta con el resto de materiales exhumados que datan de época moderna y contemporánea (Fig. 6).

La excavación del conditorium y las catas anexas a la torre permitieron completar el segundo objetivo planteado, ya que aportaron una valiosa información acerca de su cimentación y del proceso constructivo de la sepultura.

Las interfaces verticales provocadas por los expolios permitieron constatar que el nivel geológico alcanzaba en el interior del sepulcro una cota muy similar al nivel de circulación del exterior del monumento. Por lo tanto, la fosa perdida que albergaría al difunto se encontraría -pensamos- a la misma rasante. Existe un ejemplo de esta disposición en la denominada Tumba monumental de Segobriga, donde la urna de cremación que contuvo los restos óseos del difunto se situó en el interior del monumento, a la misma cota que el nivel de circulación original por el exterior (Cebrián, 2010, 141).

Se descarta, por tanto, que nuestro monumento presentara el carácter hipogeico o semi-hipogeico 


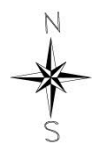

$\mathrm{B}^{\prime}$

A

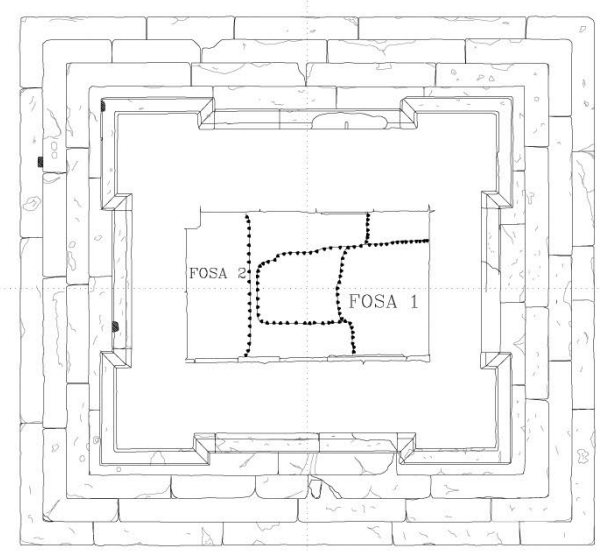

$A^{\prime}$

B
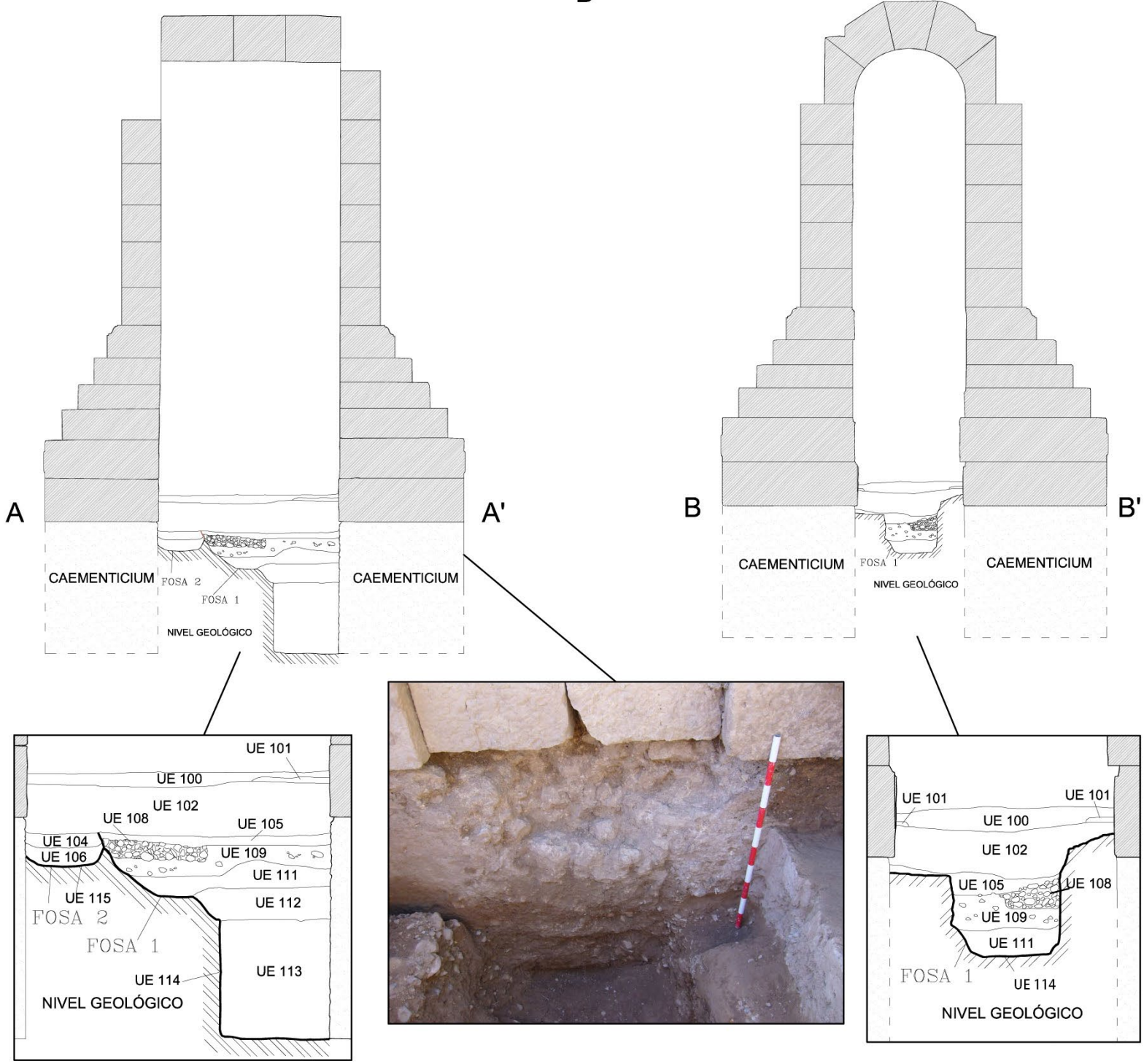

om

$5 \mathrm{~m}$

Figura 5: Sección N-S y E-O del monumento, secuencia estratigráfica del interior y vista en detalle en detalle de cimentación. 
atestiguado en monumentos como el de Facialcazar de Utrera en Sevilla, el de la «Mazmorra» de Torreparedones de Córdoba, el de la C/ La Bodega de Córdoba (Ruiz Osuna, 2008, 186-196) o el cercano hipogeo de la Alcudia de Elche fechado en el siglo I d.C., relacionado con las influencias púnicas procedentes de Almería o Cartagena (González Villaescusa, 2001, 118).

Las cimentaciones, que pensamos se llevarían a cabo tras la deposición del difunto, aparecen construidas a partir de una trinchera rectangular perimetral realizada en el nivel geológico, con una anchura de 2,16 $\mathrm{m}$ en los lados mayores y 1,83 $\mathrm{m}$ en los menores y una profundidad máxima documentada de 1,95 m. Esta zanja se rellenaría directamente con opus caementicium sin planchas de encofrado, utilizando la interfaz de la zanja como caja preparatoria, lo que explica, por un lado, la ausencia de zanjas para albergar las planchas, y por otro, el acabado imperfecto que presentan ambas caras de la estructura. Estas imperfecciones son producto de las filtraciones del hormigón antes de su secado en los estratos geológicos (Fig. 5).

Cimentaciones realizadas mediante caementicium las encontramos en bastantes monumentos funerarios, como en el cercano de Daimuz (segundo tercio del siglo II d.C.) que presentaba un cuerpo inferior con plataforma de sillares sobre cimentación de caementicium (González Villaescusa, 2001, 338; Abad y Bendala, 1985, 149), o en los dos monumentos localizados en la calle St. Vicent/Duc de Llíria de la segunda mitad del siglo I d.C. y la primera mitad del siglo II d.C. (González Villaescusa, 2001, 199-201; Jiménez, 2002, 193), que presentan cimentaciones macizas de caementicium sobre las que se asientan sendos podios escalonados (Aranegui, 1995, 198).

Sin embargo, en lo que respecta a ejemplos documentados de cimentaciones realizadas mediante una fosa perimetral, nos tenemos que remitir al monumento de la calle Muñices en Córdoba, configurado en dos cuerpos superpuestos sobre podio y fechado en los primeros años del principado de Augusto. En él se pudo documentar-gracias a una interfaz vertical de un pozo de época medieval- la presencia de una cimentación mediante zanja perimetral rellena esta vez de mampuesto y cubierta posteriormente por una capa horizontal de este mismo material, de tal forma que en el centro se conservaban los limos originales del terreno (Ruiz Osuna, 2008, 240; Vaquerizo, 2010, 118).

La trinchera rellena de caementicium de la Torre de Sant Josep serviría de base para la primera hilada de sillares, hilada que formaría parte también de la cimentación y sobre la que apoyaría el basamento escalonado del monumento cuya primera grada aparece almohadillada, marcando la cota de circulación original.

Recordemos que nuestro tercer objetivo era el de documentar las fases coetáneas al monumento en los alrededores del mismo. A día de hoy los datos recuperados sobre este periodo son exiguos, se limitan a la

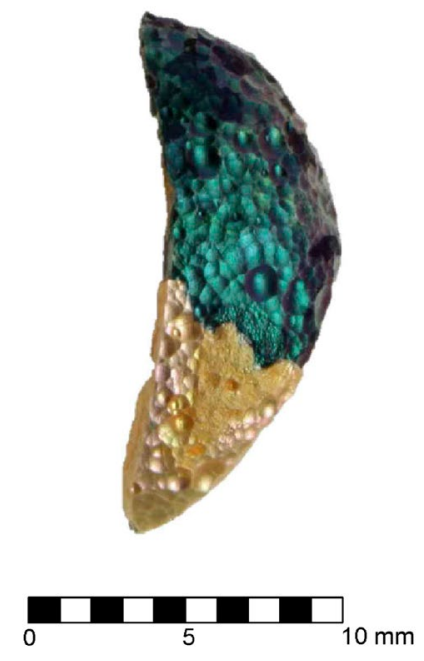

Figura 6: Fragmento de pasta vítrea localizado en el interior de la torre.

localización de un enterramiento infantil ${ }^{9}$. Esta sepultura apareció en el sector septentrional del monumento en posición decúbito lateral mirando al este, en una fosa de planta oblonga excavada directamente en el nivel geológico, y sin ningún tipo de ajuar (Fig. 3).

La secuencia estratigráfica y la ausencia de materiales asociados al enterramiento impiden determinar su cronología. Sólo conocemos que se trata de una sepultura realizada con anterioridad a la construcción de la vivienda de finales del siglo XVII / XVIII, ya que se encontraba sellada por el pavimento de una de sus estancias.

Por lo tanto, y a juzgar por los datos que tenemos en la actualidad, el enterramiento pertenecería a un momento anterior a la construcción de la vivienda; o bien a la fase datada entre el siglo XVI y XVII documentada en el 2006 en el recrecido del monumento (Fig. 2) o bien a época romana, hecho del todo plausible por los datos que explicaremos en el apartado de contextualización arqueológica arqueológica.

\section{MONUMENTO FUNERARIO}

La orientación de nuestro monumento sigue estrictamente los puntos cardinales, al igual que ocurre en numerosos monumentos hispanos turriformes o de edícula sobre podio como el sepulcro de la Torre de Breny de Manresa (Sanmartí, 1984, 113; Cid Priego, 1950, 23), la Torre de Lloret de Mar (Sanmartí, 1984, 127), la Torre del Cincho en Basilippo (Rodríguez Hidalgo, 1979-80, 429), la tumba de la calle Muñices en Córdoba (Vaquerizo, 2010, 118) o la Torre de los Escipiones de Tarraco, cuya fachada principal se

\footnotetext{
9. A la espera de un análisis antropológico más exhaustivo aún no podemos determinar si se trata de un nonato o de un neonato.
} 

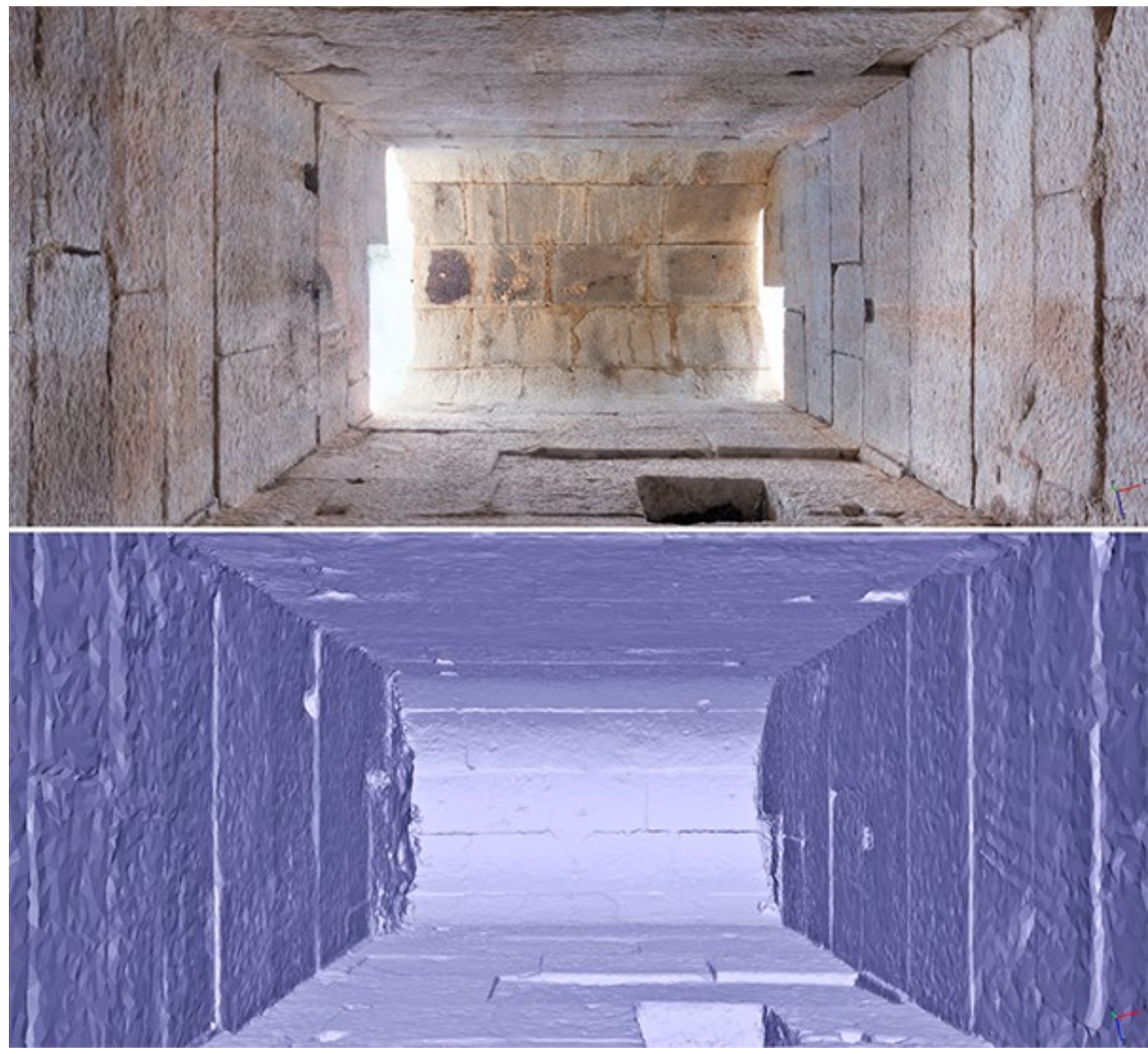

Figura 7: Vista tridimensional del modelo fotogramétrico del conditorium o interior del monumento.

encuentra orientada al sur (Sanmartí, 1984, 123), y también en sepulcros templiformes como el Mausoleo de Favara de Matarranya (Sanmartí, 1984, 92) o el Sepulcro de Boades (Sanmartí, 1984, 104).

Presenta una planta rectangular cuyos lados largos están orientados al norte y al sur y miden 6,39 $\mathrm{m}$, mientras que las medidas de los lados menores se reducen a $5,87 \mathrm{~m}$. Dimensiones similares las encontramos en el monumento de edícula de cuerpos superpuestos de Edeta con 6 x 4,55 m (González Villaescusa, 2001, 199-201; Aranegui, 1995, 198) o en el sepulcro de Miralpeix con 5,90 x 5,18 m (Cancela, 2002, 173). Sin embargo, presenta medidas menores que la Torre de Breny, de 10 x 10,5 m (Sanmartí, 1984, 112; Cid Priego, 1950, 27) y mayores que la Torre de los Escipiones, con 4,47 x 4,73 m (Sanmartí, 1984, 123) o el monumento turriforme del Hornillo de Santa Catalina de Baelo Claudia de 2,27 x 2,39 m, bastante más pequeño (Prados y García, 2010, 8), por citar algunos ejemplos.

Los restos del monumento conservados en la actualidad se elevan sobre la cimentación a la que ya nos hemos referido, mediante un basamento escalonado con cuatro gradas coronado por una moldura (gola o cyma recta). Sobre dicha moldura descansa el cuerpo principal de la torre, de planta rectangular, enmarcado por cuatro pilastras de esquinas de orden corintio con fustes lisos y basas áticas con plinto (Escrivà, 2005, 98 y 99). Los cuatro paños entre las pilastras son lisos y sin decoración. Las fachadas oriental y occidental presentan un orificio en la unión de las hiladas segunda y tercera destinado a las libaciones post-deposicionales (profusio), a través de las cuales se buscaba recordar al difunto y nutrirlo al mismo tiempo ${ }^{10}$.

El interior de la torre consta de una única cámara cerrada por una bóveda de cañón de sillería, que descansa sobre los lados mayores. En sus lados largos hemos podido apreciar la presencia de una serie de huellas rectangulares. La documentación tridimensional del interior de la cámara sepulcral ${ }^{11}$ (Fig. 7) ha permitido determinar con precisión las medidas de éstas

10. Este tipo de banquetes post-deposicionales se realizaban en fechas relacionadas directamente con el difunto; el día de su nacimiento (dies natalis), o el aniversario de su muerte (dies mortis), o bien en los días que el calendario romano reservaba explícitamente para el culto a los muertos, distribuidos entre febrero y junio: Parentalia, Lemunaria, Rosalia, etc. (Vaquerizo, 2010, 20).

11. Los trabajos de virtualización y documentación del interior del monumento fueron realizados por Daniel Tejerina, arqueólogo. 


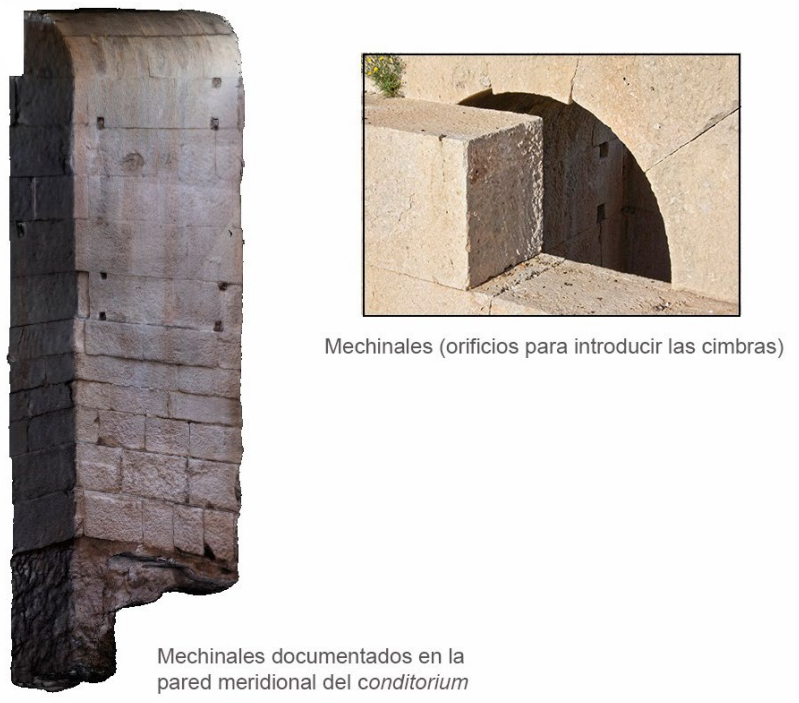

Figura 8: Marcas de los agujeros de las cimbras del interior del monumento.

y a su vez comprobar que se trata de huecos rectangulares alineados horizontalmente en franjas enfrentadas (Fig. 8).

Tras la realización de las ortofotos de los alzados internos del monumento, hemos apreciado que se repetían una serie de medidas correspondientes a 3 digiti romanos $^{12}$, hecho que nos lleva a descartar que se trate de remodelaciones de fases posteriores que hubiesen podido dejar su impronta en el edificio ${ }^{13}$. A partir de estos datos y dado que el primer grupo de huellas se encuentra en la línea de sillares inmediatamente anterior al arranque de la bóveda (línea de imposta), pensamos que se puede tratar de los huecos (mechinales) para encajar los armazones de madera o cimbras para la construcción de la misma (Adam, 1989, 189; Zugmeyer y Badie, 2012, 109, fig. 5). La segunda línea de huellas estaría destinada a la sujeción de una plataforma de andamiaje situada aproximadamente en el centro del alzado de la cámara interna de la torre. Este tipo de perforaciones para andamiajes, aunque de forma circular, los encontramos en el sepulcro turriforme de Vildé en Soria realizado en opus caementicium (García Merino, 1977, 43).

\section{RESTITUCIÓN}

La hipótesis de reconstrucción del sepulcro realizada por L. Abad y M. Bendala en 1985 sigue siendo váli$\mathrm{da}$, ya que no se ha visto contradicha con los trabajos

12. 1 digitus es igual a $18,481 \mathrm{~mm}$, por tanto, los $57 \mathrm{~mm}$ que presentan los orificios equivalen a 3 digiti.

13. Además los trabajos realizados por Abad y Bendala (1985, 166, fig. 23) documentaron las remodelaciones de época moderna del interior del monumento y en ningún caso coinciden con los huecos a los que hacemos referencia. posteriores realizados hasta día de hoy, sino, más bien, confirmada.

Las recientes intervenciones arqueológicas han dado a conocer nuevas piezas del monumento, que hay que sumar a las documentadas en los trabajos de la década de los 80 y como ya hemos comentando han permitido liberarlo de los edificios anexos de fases posteriores.

Los trabajos se han realizado sobre todo el conjunto de elementos arquitectónicos, creando un registro fotogramétrico que ha permitido obtener una planimetría precisa de cada uno de los alzados de la torre, así como de la planta en su estado actual. Se ha realizado una numeración y documentación individualizada y detallada de cada uno de los elementos arquitectónicos que se encuentran en la actualidad en las inmediaciones del edificio, un total de 25. Estos datos se plasmaron en fichas individualizadas que recogen las características de cada uno de los elementos arquitectónicos (medidas, descripción, documentación fotográfica, dibujo arqueológico y croquis con su ubicación actual).

Esto ha permitido aportar a las hipótesis teóricas planteadas con anterioridad un registro fotogramétrico tridimensional del total de elementos arquitectónicos conocidos a día de hoy.

\subsection{CRiterios SEguidos EN LA Restitución DEL MONUMENTO}

Para la ubicación de los sillares dentro del monumento se han seguido dos guías de referencia. Por un lado, la tipología arquitectónica del monumento y la reconstrucción metrológica del edificio, y por otro, la información obtenida de cada uno de los sillares de forma individualizada.

\subsubsection{Análisis tipológico del monumento}

La clasificación y búsqueda de paralelos del tipo arquitectónico de este monumento resulta compleja, dado que los monumentos funerarios romanos no están sujetos a unos cánones arquitectónicos muy estrictos.

Existen tres teorías sobre el origen de las torres funerarias romanas.

La primera apunta a que esta tipología surgió dentro del mundo romano y tuvo sus raíces en el mundo helenístico, tal y como formula Kovacsovics (1983, 26). Las otras dos teorías apuestan por que Roma asimiló este modelo del exterior, o bien del mundo púnico a través del norte de África (Poinsont y Salmonson, 1963), o bien del mundo oriental (Kockel, 1983). En el norte de África los sepulcros turriformes van evolucionando a lo largo de las épocas; sin embargo, en la mayoría de ellos podemos encontrar muchos de los elementos identificables en la Torre de Sant Josep, como que se elevan sobre zócalo escalonado, que son de un solo cuerpo cuadrado, que tienen pilastras 
(corintias) adosadas y que están rematados por coronamientos piramidales. Así, en época púnica podemos encontrar dos monumentos muy similares al nuestro: los de Thugga y Es Sumáa (Rakob, 1979; Cid Priego, 1949). El de Thugga es un mausoleo púnico del siglo II a.C. a caballo entre los monumentos turriformes y los sepulcros de aguja (Romanelli, 1970, 272). Si nos trasladamos a época helenística, encontramos tres monumentos más, el de Kar Tenacef (Gsell, 1901), el de Zawani (Stucchi, 1975) y finalmente, el de Akbou, una excepción entre los monumentos norteafricanos, que suelen tener varias plantas. El de Akbou tiene una sola, lo que lo convierte en el ejemplo más próximo a nuestra torre (Romanelli, 1970, 270; Cid Priego, 1949, 119, fig. 13). Y entre los monumentos más cercanos cronológicamente al nuestro, encontramos el sepulcro turriforme de Leptis Magna o los de Maktar datados en el siglo II d.C. (Romanelli, 1970; Prados Martínez, 2008, 287, fig. 317).

Los monumentos funerarios en el mundo oriental derivan de la arquitectura del Mausoleo de Halicarnaso. $Y$ aunque se pueden encontrar ejemplos similares al de la Torre de Sant Josep, como el de Dana-Sud en Siria (Herman, 1964) o el de Hermel en Baalbeck (Will, 1949), los sepulcros turriformes orientales difieren en su arquitectura del nuestro en que por regla general carecen de podio y suelen presentar cámaras superpuestas en su interior.

Si hemos de buscar las raíces del monumento romano de Sant Josep en Europa, encontramos una serie de monumentos como la Tumba de Pompeyo Magno en Albano, los de M. Vergilius Eurysaces y C. Poblicius Bibulus en Roma y el de Calvius Turpius en Lyon (Kovacsovics, 1983). Su esquema general suele ser un pódium liso o escalonado y uno o dos cuerpos de edícula cerrada con pilastras adosadas. Todos son monumentos de época augustea, y parecen ser la culminación de una evolución iniciada en el siglo II a.C. por el monumento de la Tumba de Terón en Agrigento (Gamer, 1981; Marconi, 1929) y continuada por la Tumba de las Guirnaldas en Pompeya en el siglo I a.C. (Gabelman, 1979; Kockel, 1983; Gross, 2002, 14).

En la Península Ibérica, además de la Torre de Sant Josep destacan cinco sepulcros de esta tipología; la Torre de los Escipiones en Tarragona, de zócalo liso y dos cuerpos diferenciados por una línea de molduras (AAVV. 1993; Cid Priego, 1947-1948; Gamer, 1981; Sanmartí, 1984, 123-124), la Torre del Breny en Barcelona (Cid Priego, 1950; Sanmartí, 1984 113-114), el monumento de Vilablareix (Sanmartí,124-126) y el de Basilippo (Rodríguez Hidalgo, 1979-1980). Y como sepulcro hispano que no ha llegado hasta nuestros días podíamos citar también la torre de Daimuz, tan similar a la de Villajoyosa, que como afirman Abad y Bendala se podría atribuir al mismo taller.

Si miramos más en detalle algunos elementos arquitectónicos podemos encontrar paralelos en cuanto a la disposición exterior, la cubierta y el espacio interior del monumento funerario de la torre de Sant Josep.
Si nos fijamos en la disposición exterior de los elementos arquitectónicos, la mayoría de los paralelos con la Torre de Sant Josep dentro del área occidental del imperio romano carecen de basamento escalonado, y en los que existe, o bien es un pódium muy bajo, como los de la tholos de Aquileia, el de St. Remy, la tumba de Cartilius Popicola en Ostia (Gismondi, 1958), y los de C. Spectatus Priscianus y los Secundiani en Sempeter, o bien las gradas apenas sobresalen unas de otras, como en el de las Guirnaldas en Pompeya (Gabelmann, 1979; Gross, 2002, 14), o el de Igel en Tréveris (Zahn, 1982). Tenemos, por tanto, que acudir a los monumentos norteafricanos contemporáneos para encontrar este tipo de podio escalonado. Esta relación nos estaría indicando o bien un origen norteafricano de este tipo de monumentos o bien un desarrollo paralelo a partir de modelos anteriores comunes.

En cuanto a la existencia en nuestra torre de uno o dos cuerpos sobre el basamento escalonado, nos decantamos por la propuesta de un solo cuerpo defendida por Abad y Bendala y posteriormente por Gros (Abad y Bendala, 1985; Gros, 2001, 416), al igual que ocurre en el monumento Hornillo de Santa Catalina de Baelo Claudia (Prados, 2011, 197) o en el cercano monumento de Daimuz tan similar al nuestro (Abad y Bendala, 1985, 177). A lo largo de nuestra investigación hemos encontrado argumentos nuevos que avalan esta hipótesis y que desarrollamos a continuación.

El alzado máximo del cuerpo conservado de la torre es de $3,75 \mathrm{~m}$, altura a la que tendría que iniciarse el segundo cuerpo. Pero entre las distintas piezas molduradas existentes no hay ninguna que pueda ubicarse en esta posición, ya que las dos mejor conservadas (sillares $n^{\circ} 17$ y 22 ) presentan mortajas de cola de milano en la parte posterior. Ello indica que tienen que unirse a sillares traseros que pudieron formar parte de una plataforma intermedia entre los dos cuerpos y que en cualquier caso necesitan un espacio donde alojarse. Pero en ese lugar no es posible ni lo uno ni lo otro, ya que por detrás se encuentra directamente la bóveda interior.

Ese espacio sólo existe a partir de 5,10 m, ya por encima de la bóveda, y a esa altura habría que añadir la del entablamento, lo que daría una altura de $6,83 \mathrm{~m}$ para el cuerpo inferior de la torre según la propuesta de von Hesberg (Hesberg, 1993, 161). Esta altura sería mucho mayor que la existente en monumentos hispanos de dos cuerpos con plantas de dimensiones similares, como el Sepulcro de Miralpeix, con un primer cuerpo de 3,22 m (Sanmartí, 1984,108-109); el primer cuerpo del de Edeta sería, según Aranegui, de 4,25 m (Aranegui, 1995, 205); y el de la Torre de los Escipiones de 3,80 m, aunque en este último las dimensiones de su planta son un poco menores que las del nuestro (Sanmartí, 1984, 123).

Por lo tanto, el primer cuerpo de nuestro monumento sería demasiado elevado, en comparación con los paralelos mencionados, para sostener un segundo cuerpo de dimensiones proporcionadas. Es algo que 
no parece probable, a juzgar por los datos de que disponemos, y tampoco se corresponde con la metrología propuesta para el monumento a la que nos referiremos más adelante.

Parece que en la base de la propuesta de Hesberg $(1993,165)$ se encuentra la equiparación del monumento de Villajoyosa con las torres de los Escipiones y de Miralpeix, interpretando su piso inferior como una especie de pódium que quedaría incompleto si no se le añadiera una edícula o un segundo piso que acentuara su carácter turriforme.

Sin embargo, opinamos que el cuerpo inferior de la Torre de los Escipiones no es equiparable al de la Torre de la Vila ni en cuanto a dimensiones, como ya hemos visto, ni en cuanto a función arquitectónica, pues el cuerpo del monumento de Villajoyosa tiene más entidad que la de un simple pódium y puede constituir un cuerpo del monumento, que en este caso sería el único y principal.

Abad y Bendala indican también que cuando el edificio cuenta con varios cuerpos, la edícula que suelen tener se encuentra siempre en el superior. El monumento de Daimuz, que tiene una muy estrecha relación metrológica y formal con el nuestro, presenta la edícula en el primer cuerpo, por lo que parece evidente que este era el único que existía. Lo mismo ocurriría en el de Villajoyosa, aunque en este caso no exista edícula. Pudo ser que no existiera, pero también que se hiciera en un ligero relieve de estuco o que simplemente estuviera pintada sobre una de sus fachadas.

Pensamos que el resto del monumento pudo encontrarse también enlucido y pintado ${ }^{14}$, hecho frecuente en el contexto general de la arquitectura antigua y romana y que explicaría el tratamiento final de la epidermis delicadamente rugosa de muchos de los sillares, como a la espera de una terminación estucada. Ya Hauschild había apuntado en 1993 que el capitel corintio que se encontraba en los alrededores de la torre podía haber tenido sus detalles labrados en estuco (Hauschild, 1993, 403).

En cuanto al tipo de cubierta, podemos decir que la más característica de este tipo de monumentos es la pirámide de lados curvos, sobre todo los de la zona del Rin. Sin embargo, dada la mayor similitud de nuestro monumento con los de la misma época del norte de África, parece lógico atribuirle a éste también, como ocurre en los norteafricanos, una pirámide de lados lisos.

Atendiendo a la característica de monumento con cámara interior, podemos decir que los monumentos orientales y los africanos suelen tener sus estancias interiores comunicadas con el exterior. Sin embargo, los europeos suelen carecer de cámara funeraria, y en el caso de existir, ésta o bien es maciza-Torre de las Guirnaldas, Torre de Hermel (Torelli, 1968) y Torre

14. Esta idea nos la ha sugerido Manuel Bendala en una visita reciente al monumento.
Ciega de Cartagena (Abad, 2003, 92) - o bien es inaccesible desde el exterior, como la Torre de los Escipiones (Sanmartí, 1984, 123-111), la de Miralpeix (Sanmartí, 1984, 108-111) o la de Daimuz. La torre de Sant Josep entraría dentro de este último grupo, ya que posee una cámara interior, sin comunicación desde el exterior, exceptuando los agujeros para las libaciones.

En resumen, y a juzgar por los paralelos descritos, creemos poder concluir que la torre de Sant Josep es un monumento turriforme de los denominados de edícula cerrada, compuesto por un basamento, un cuerpo principal y un remate piramidal.

\subsubsection{Metrología del edificio}

Para la reconstrucción métrica del edificio -aunque las proporciones son meramente aproximadas, ya que no existe ninguna relación proporcional fija entre las diferentes partes de estas construcciones- nos volvemos a remitir a los trabajos realizados por Abad y Bendala $(1985,162)$, que establecen una proporción de 2:1 para el monumento, habitual en estos $\operatorname{casos}^{15}$.

Si partimos de esta base y utilizamos el pie romano $(0,296 \mathrm{~m})$ como unidad métrica proponemos, aunque con algunos pequeños desajustes, las siguientes relaciones:

- La longitud del escalón inferior del lado mayor de la torre, que es de 21,5 pies, daría una altura total del monumento, incluido pyramidium, de 43 pies (Fig. 18), de acuerdo con la proporción canónica romana.

- Con estas proporciones, pensamos que el cuerpo principal del monumento, incluyendo basa y capitel debió medir 17 pies. Para alcanzar esta altura reconstruida del cuerpo principal, es necesaria la existencia de un total de 8 hiladas, de las cuales se conservan íntegramente las cinco inferiores y una sexta de forma parcial; por tanto, en la restitución añadimos una hilada más de lienzo liso y una octava correspondiente a la línea de capiteles que coronarían las pilastras y con ello el cuerpo principal de la torre.

- El entablamento, formado por las piezas conservadas de arquitrabe, las probables piezas pertenecientes al friso y los cinco fragmentos de cornisa, pensamos que presentaría una altura de 6 pies. De estos elementos hablaremos en detalle más adelante.

- Y finalmente, iría coronada por el hipotético pyramidium, que alcanzaría 12,25 pies $^{16}$.

15. Proporción utilizada también como referencia en la propuesta de restitución del monumento hispano de la Ermita de la Virgen del Cid (Arasa, 1987, 169).

16. Los datos resultantes tras el estudio realizado de los sillares y la fotogrametría varían tan solo medio pie romano con respecto a las medidas hipotéticas propuestas por Abad y Bendala. 

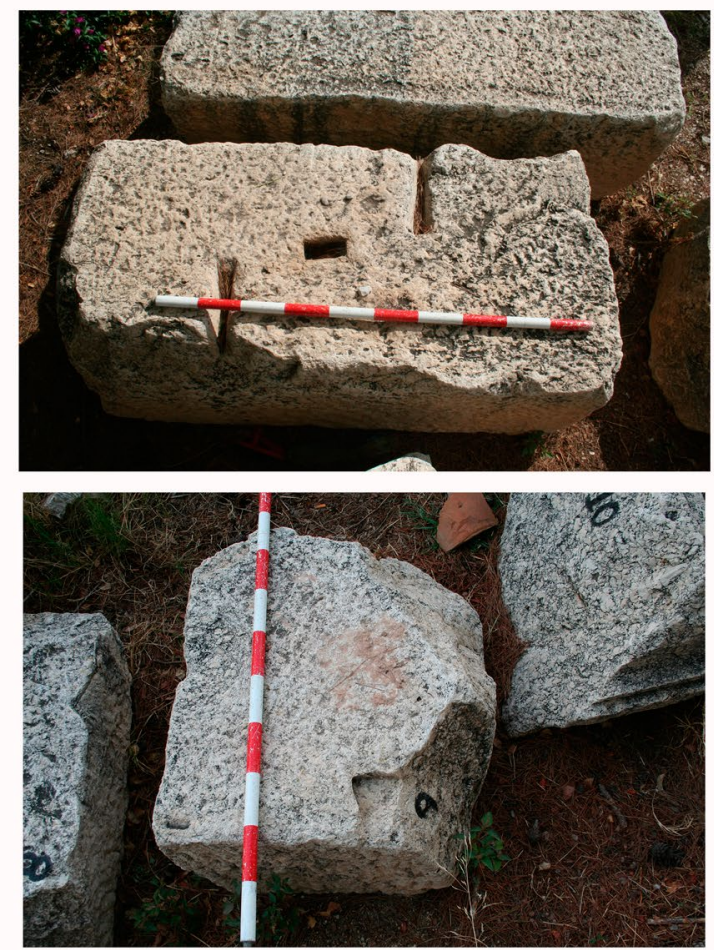
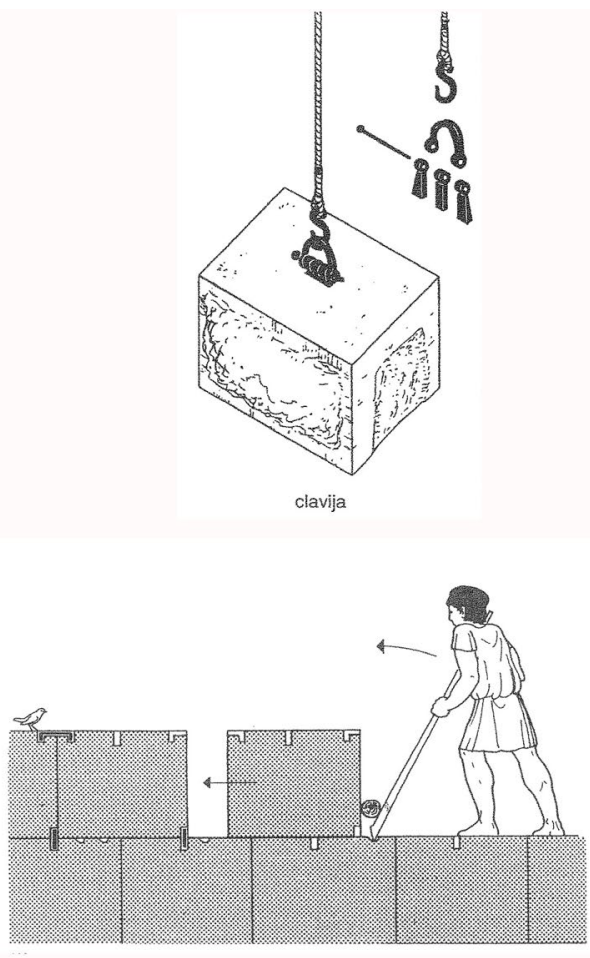

Figura 9: A la izquierda, sillares 3 y 9 con cavidad rectangular central, pinzas de desplazamiento y mortajas de cola de milano. A la derecha, recreación del traslado de sillares con cavidad rectangular central mediante clavijas. (Adam, 1989, 50-52, fig. 110) y recreación del desplazamiento de sillares mediante agujeros de pinzas para hacer palanca (Adam, 1989, 55, fig. 119).

4.1.3. Información métrica y tipológica de los sillares individualizados

En primer lugar, se han establecido grupos de sillares por módulos métricos, es decir, longitud, anchura (profundidad del sillar) y altura -esta última la más representativa-y por los tipos de moldura que presentan algunos de ellos. Estos datos nos sirvieron para una primera clasificación de los elementos o sillares que, a priori y en base a estos criterios, pertenecían o no al monumento.

$\mathrm{Y}$ en segundo lugar nos hemos guiado por las marcas presentes en los sillares estudiados. La gran mayoría presentan una cavidad rectangular de boca más estrecha que la base (con perfil de «cola de milano») preparada por el cantero en el centro de gravedad de la cara superior de cada bloque (sobrelecho) para introducir en él las que Adam denomina 'castañuelas', que actuarían como gancho de elevación para transportarlo a su lugar (Adam, 1989, 50-52, fig. 102 y 110). Este orificio nos ha aportado información, por un lado, acerca de la orientación de las caras del sillar, dado que la cavidad rectangular aparece sistemáticamente en el sobrelecho, y por otro ha permitido reconstruir la longitud y anchura de los sillares incompletos al actuar como punto central de referencia de los ejes del sillar. Ambos constituyen criterios válidos para su ubicación en el monumento. Asimismo, en los laterales de varios sillares hemos atestiguado la presencia de mortajas en forma de cola de milano, lo que nos ha permitido ubicarlos en la línea de cornisa o lo que es lo mismo, de cierre del cuerpo principal del monumento, hecho al que haremos referencia más adelante (Fig. 9).

\subsection{PRopuesta DE RESTITUCIÓN POR HILADAS}

Hiladas $6^{\mathrm{a}}$ y $7^{\mathrm{a}}$ (Figs. 10 y 11 )

Consideramos que la altura de estas hiladas es de $0,67 / 0,68 \mathrm{~m}$ (altura de la última hilada conservada), mientras que la profundidad que deben presentar es de $0,45 / 0,41 \mathrm{~m}$ en los lados mayores y de $0,62 \mathrm{~m}$ o algo menos en los menores, medidas estas últimas determinadas por el espacio resultante entre la línea exterior del lienzo y la bóveda interior.

Con estas variantes tenemos situados en los lados menores:

El sillar $\mathrm{n}^{\circ} 6$, que presenta $0,68 \mathrm{~m}$ de altura por $0,61 \mathrm{~m}$ de profundidad y el sillar $\mathrm{n}^{\mathrm{o}} 2$, que presenta $0,67 \mathrm{~m}$ de altura por $0,61 \mathrm{~m}$ de profundidad. Dicha ubicación sería sólo en el caso de no llevar cavidad rectangular central, dato que no se aprecia pero podría estar en el lado sobre el que yace el sillar actualmente, y por tanto, no ser visible ${ }^{17}$.

17. En el caso de llevar cavidad rectangular central podría optarse por la ubicación del sillar en la octava hilada siempre y cuando el sillar 1 no se ubicara en esta misma hilada, ya que si fuera así no podría albergar los dos sillares, que tendrían 
Hilada $6^{a}$

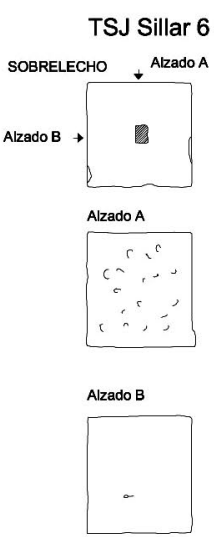

Hilada $7^{\mathrm{a}}$

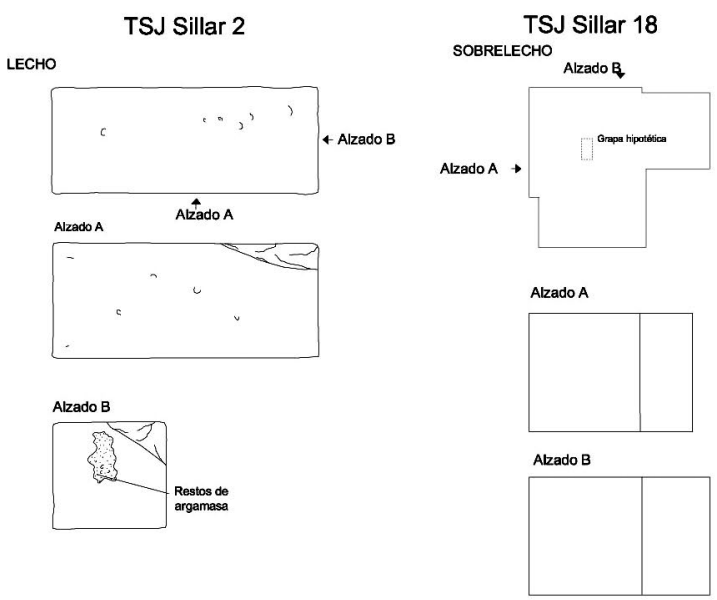

\section{Hilada $8^{a}$}
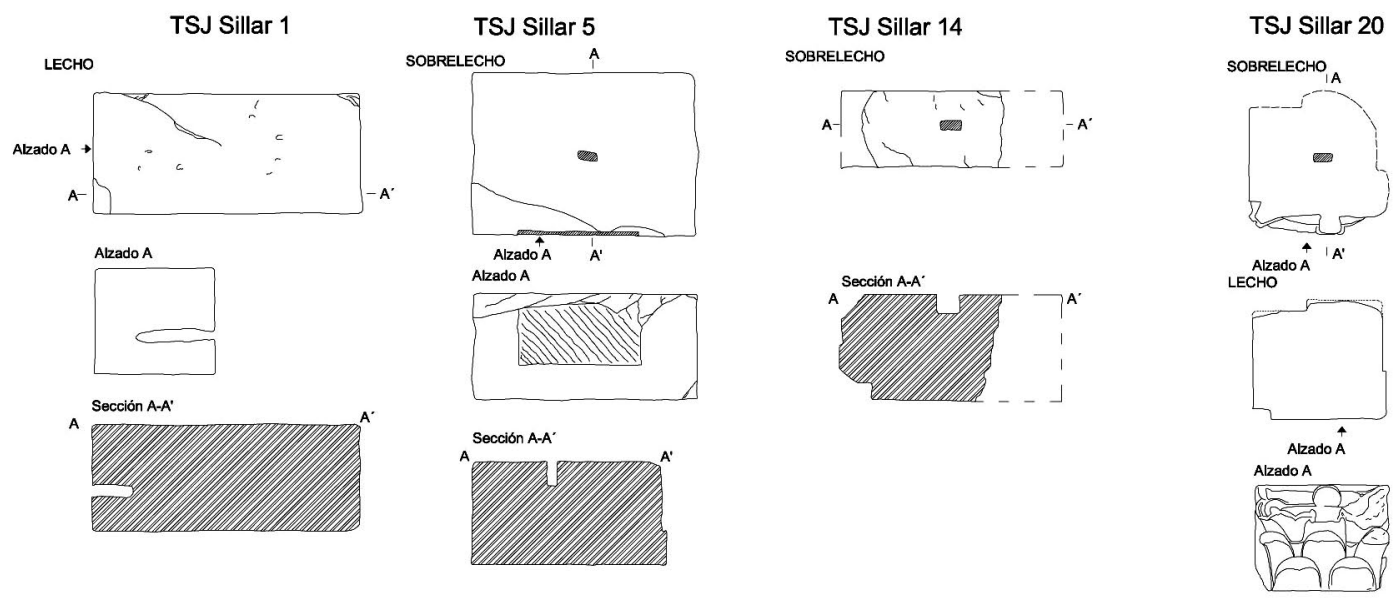

Sección A-A'
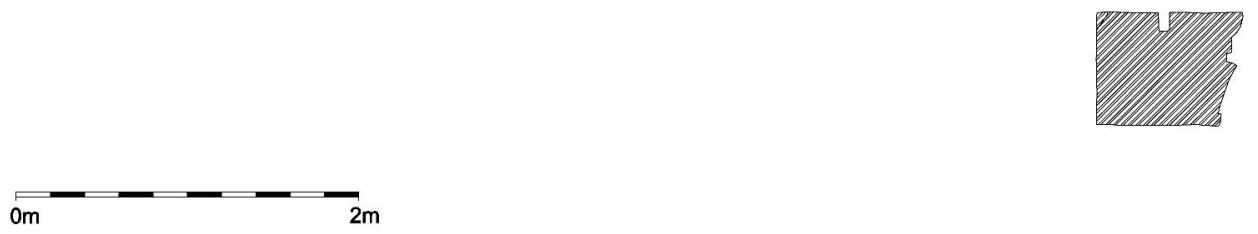

Figura 10: Dibujos de sillares ubicados en las hiladas $6^{\mathrm{a}}, 7^{\mathrm{a}}$ y $8^{\mathrm{a}}$.

Y finalmente el sillar $\mathrm{n}^{\circ} 18$, que forma ahora parte de uno de los aterrazamientos contemporáneos existentes al sur de la torre, por lo que sólo podemos ver dos de sus caras. Interpretamos que una de las caras visibles es el alzado exterior del sillar (alzado B, Fig.

que situarse necesariamente en el flanco mayor norte del monumento debido a que el flanco sur está ocupado por el sillar $n^{\circ} 5$ (posible inscripción).
10) y la otra, al no llevar cavidad rectangular central, es su base (lecho). Si colocamos el sillar sobre lo que interpretamos que es su lecho, nos muestra que nos encontramos ante uno de los sillares esquineros, ya que presenta dos de sus lados trabajados reproduciendo una esquina de pilastra que encaja con las pilastras del monumento. Dada su tipología, el sillar tiene dos posibles ubicaciones dentro de la torre; en la sexta o séptima hilada de la esquina noroeste y en la séptima hilada de la esquina sureste. Tras estudiar dichas 
$\frac{1}{s}$

Hilada $6^{\circ}$

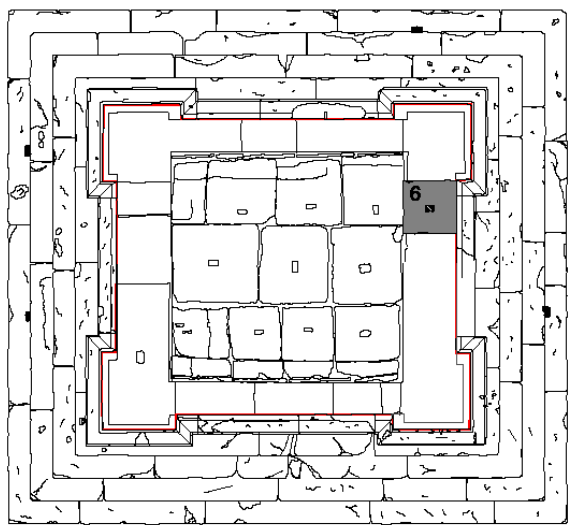

Hilada $7^{\circ}$
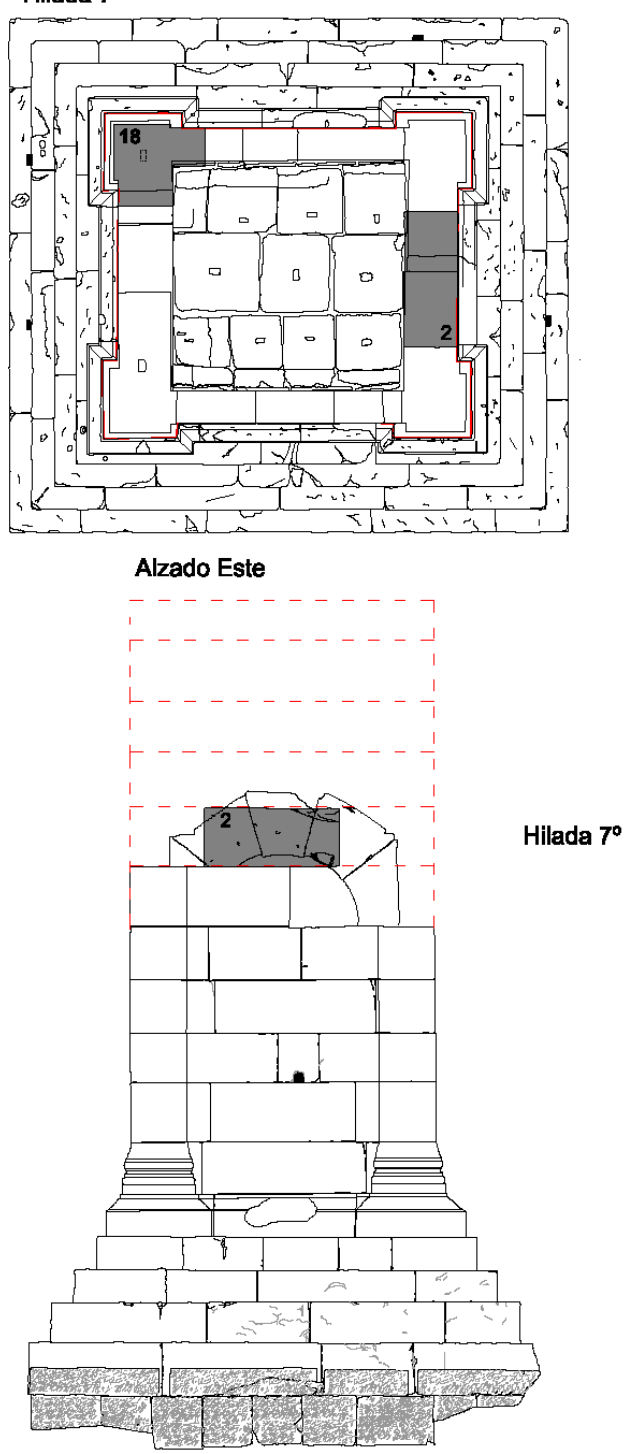
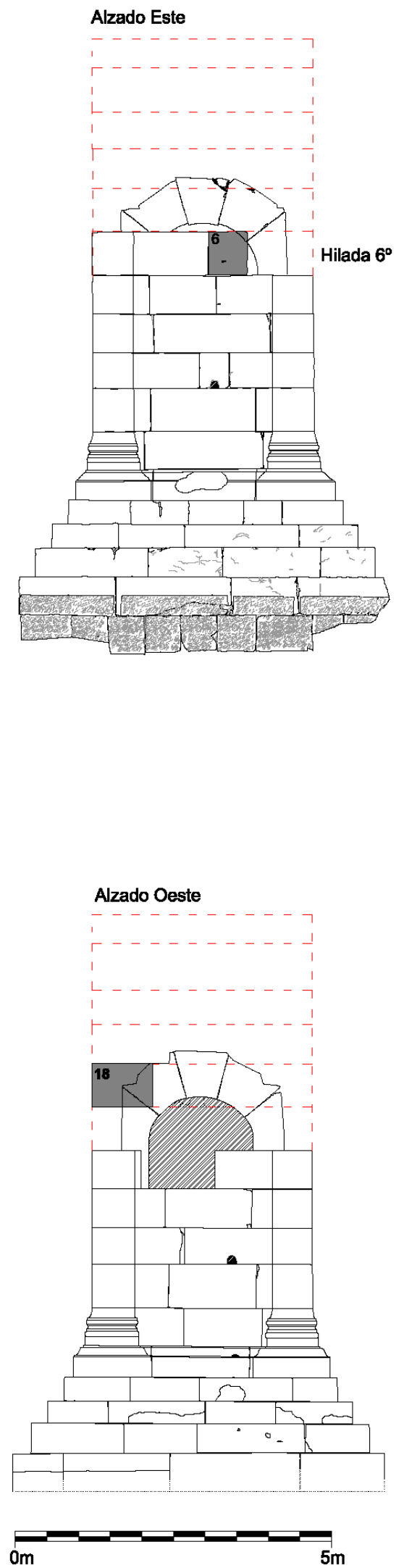

Figura 11: Ubicación hipotética de los sillares documentados en las hiladas $6^{\mathrm{a}}$ y $7^{\mathrm{a}}$. 
ubicaciones, el sillar se ajusta más adecuadamente a la esquina noroeste de cualquiera de las hiladas $6^{\mathrm{a}}$ y $7^{\mathrm{a}}$ de esta pilastra, dado que sus caras interiores se adaptan mejor a este lado de la bóveda del monumento.

Hilada $8^{\text {a }}$ (Línea de capiteles, Fig. 10 y 13)

Las proporciones que marcan la altura del cuerpo principal de la torre y la altura total del monumento explicadas anteriormente llevan a que esta octava hilada corresponda a la línea de capiteles que coronan las pilastras, antes de dar paso al entablamento. Por tanto, es en esta hilada donde se ubicaría el único capitel que ha llegado hasta nosotros inventariado como $n^{\circ} 20$. Se trata de un capitel corintio del tipo «capitel esbozado», datable según la serie de Pensabene para Ostia en los años centrales del siglo II d.C. (Abad y Bendala, 1985, 168-169) y del que también encontramos algún ejemplo en Hispania, concretamente en Emérita Augusta (Díaz Martos, 1985) (Fig. 12).

La segunda pieza que pensamos pertenece a esta hilada corresponde al sillar $n^{\circ} 5$ (Fig. 12). Se trata de un sillar rectangular con cavidad rectangular central en el sobrelecho que presenta en una de sus caras un rebaje también rectangular de 0,71 x 0,41 x 0,06 m donde podría ir ubicada la placa con la inscripción funeraria del monumento (Abad, 2011, 210, fig. 12).

La ubicación de las inscripciones funerarias dentro de los monumentos no está sujeta a normas fijas. Pueden estar situadas en la parte alta del basamento, como en la Torre de Vilablareix (Sanmartí, 1984, 126); en la parte inferior del cuerpo principal, como en la Torre de Daimuz (González Villaescusa, 2001, 338; Sanmartí, 1984, 114; Abad y Bendala, 1985, 149, fig. 3); en la zona central del cuerpo principal, como en la Torre Ciega de Cartagena (Abad, 2003, 93; Sanmartí, 1984, 132); en la parte superior del cuerpo principal, como en la tumba de Calvius Turpius de Lyon (hilada inmediatamente inferior a la línea de los capiteles), en los monumentos funerarios denominados Edificio $I$ y $I I$ de la calle Almendralejo no 41 en Augusta Emérita (Heras y Olmedo, 2010, 48), en la Torre de los Escipiones y en la Torre del Breny (Sanmartí, 1984, 112-113); o en el friso, como ocurre en el mausoleo de Favara, en el mausoleo de los Atilii en Sádaba o en el monumento de Chiprana (Sanmartí, 1984, 90-100).

En nuestro caso creemos que el sillar $n^{\circ} 5$, posible soporte de la inscripción, se ubicaría en esta octava hilada del cuerpo principal del monumento, debido por un lado a la profundidad del sillar $(0,95 \mathrm{~m})$ que hace imposible que forme parte de las hiladas inferiores a ésta, ya que el espacio resultante entre la línea de lienzo exterior y la bóveda del monumento no es suficiente para albergarlo. Y por otro lado pensamos que no iría en las hiladas superiores a la $8^{\mathrm{a}}$, es decir, en el entablamento, ya que sólo podría posicionarse en la línea de friso, y esta ubicación presenta dos problemas: primero, la amplia profundidad del sillar rompería la
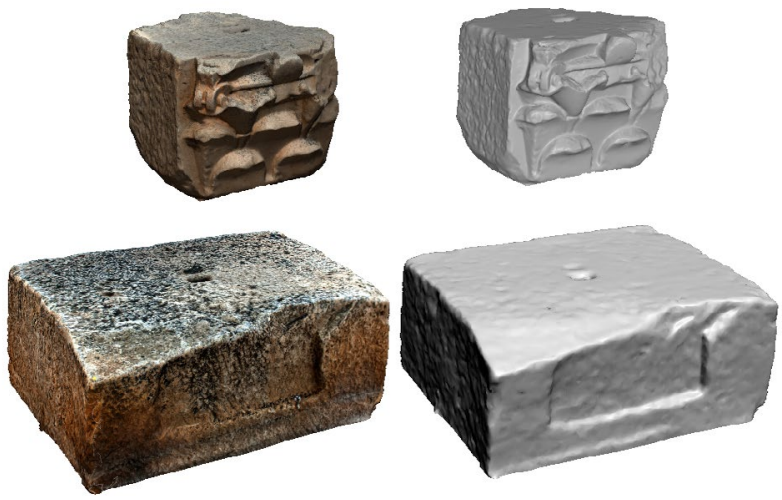

Figura 12: Modelo fotogramétrico tridimensional de los sillares 20 (capitel) y 5.

línea de lienzo interno del monumento, y segundo, las reducidas dimensiones de la inscripción $0,71 \mathrm{~m}$ x 0,41 $\mathrm{m}$, impedirían una buena percepción del titulus sepulcralis a tanta altura.

Finalmente, los trabajos de levantamiento y virtualización del monumento nos permiten afinar más aún y situar esta pieza concretamente en la cara sur del mismo, uno de sus lados mayores, ya que en ésta la bóveda presenta un rebaje que pensamos podría estar destinado a asentar el peso del sillar en profundidad (Fig. 13).

En cuanto al tipo de inscripción que podría albergar el sillar 5, tendría que consistir en una placa epigráfica, tipo de soporte predominante en el área meridional de la zona valenciana en estas fechas (siglo II d.C.), ya que por influencia de Carthago Noua los bloques epigráficos se vieron sustituidos en muchos casos por placas más livianas (Cebrián 2000, 199 y Jiménez, 2001, 198). Las dimensiones de la hipotética placa son 1,38 pies $(0,41 \mathrm{~m}) \times 2,4$ pies $(0,71 \mathrm{~m}) \times 0,2$ pies $(0,06 \mathrm{~m})$ y encajaría dentro del grupo de placas epigráficas de mayores dimensiones de época antonina localizadas en tierras valencianas $(1 / 2$ pies $\mathrm{x} 1 / 2,5$ pies x 0,06 / 0,6 pies) (Cebrián, 2000, 220).

Una vez establecida la hipótesis de la ubicación de la inscripción en el monumento queda por considerar la legibilidad del titulus sepulcralis ubicado a $6,95 \mathrm{~m}$ de altura respecto al nivel de circulación de época romana. Para ello, hemos planteado de forma hipotética un máximo de cuatro líneas epigráficas, lo que implicaba una altura aproximada de letras de $7 \mathrm{~cm}$. A partir de esta propuesta se llevó a cabo una recreación virtual hipotética de la posible placa en el monumento, lo que nos permitió comprobar la visual que tendría un individuo de estatura media desde el nivel de circulación romano, confirmando la posibilidad de que una inscripción funeraria de estas características y en esa ubicación constituyera el titulus sepulcralis de nuestra sepultura (Fig. 14). Si el número de líneas fuera menor, la altura de las letras aumentaría en proporción.

A pesar de que esta hipótesis parece lógica, no podemos pasar por alto el hecho de que la cara del sillar en la que aparece el rebaje que albergaría la 
$\frac{N}{4}$

Hilada 8* (línea de capiteles)

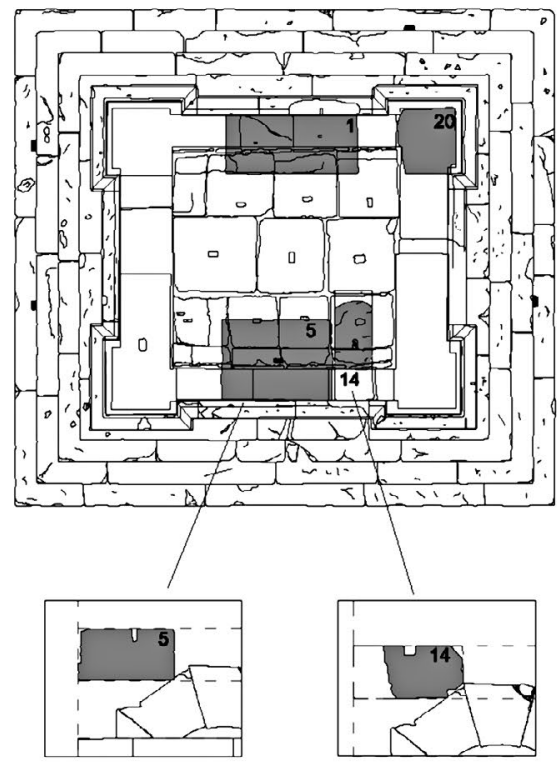

Sillares 5 y 14 en el alzado Este

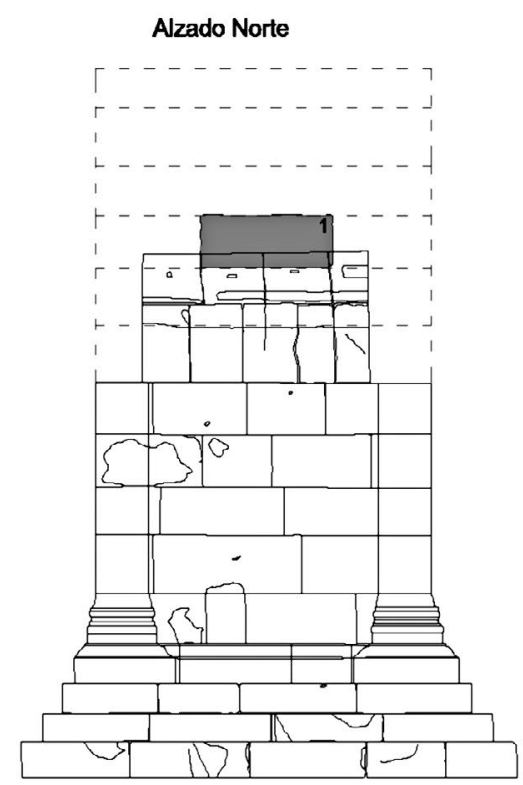

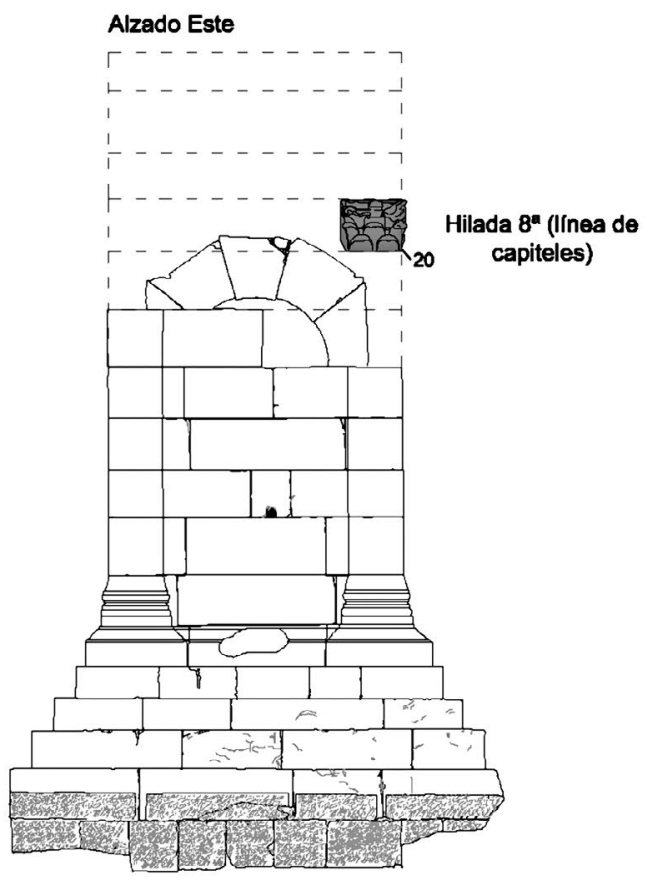

Alzado Sur
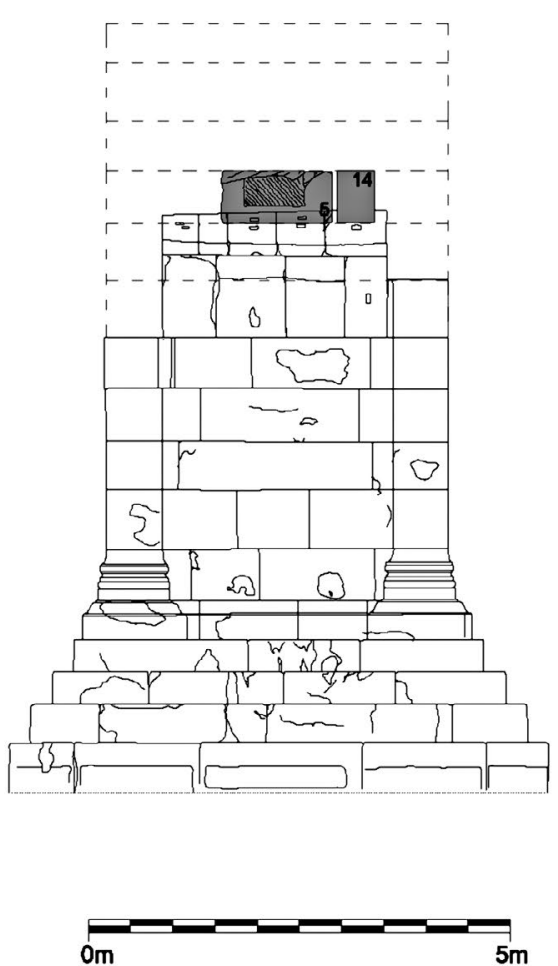

Figura 13: Ubicación hipotética de los sillares documentados en la hilada $8^{\mathrm{a}}$. 
inscripción, y por tanto su cara visible, presenta una superficie menos trabajada que la cara opuesta. Ello podría deberse a que el rebaje tuviera una función constructiva y a que la cara visible del sillar fuera en realidad la opuesta, lo que implicaría la ausencia hasta el momento de elementos relacionados con el epígrafe de la sepultura. De todas formas, éste, en caso de existir, no necesariamente tendría que estar inscrito en una placa marmórea; podría estarlo en un sillar e incluso ir acompañado de algún tipo de relieve, como ocurre en el monumento de la Calerilla de Hortunas (Requena) (Martínez Valle, 1995, 266-270).

En esta misma hilada creemos que se ubicaría también el sillar $n^{\circ} 14$, principalmente porque presenta un rebaje escalonado en uno de sus lados menores, anathyrosis que se adapta perfectamente a la bóveda de la torre en el flanco sur del monumento (Fig. 13).

Por tanto, la altura de esta $8^{a}$ hilada sería de $0,62 / 0,64 \mathrm{~m}$, determinada por el capitel conservado y por la altura de los sillares $\mathrm{n}^{\circ} 5$ y n $\mathrm{n}^{\mathrm{o}} 14$, Esta variación mínima de dos centímetros pensamos que está provocada por la ubicación en diferentes flancos del monumento de las piezas citadas (sillares $\mathrm{n}^{\mathrm{o}} 5 \mathrm{y} \mathrm{n} \mathrm{n}^{\mathrm{o}} 14$ en el flanco sur y capitel $n^{\circ} 20$ en el flanco norte).

Finalmente creemos que esta hilada también albergaría el sillar $\mathrm{n}^{\mathrm{o}} 1$ en el flanco mayor norte, ya que presenta una altura de $0,62 \mathrm{~m}$ y una profundidad de 0,70 m (medida mayor de la que podrían albergar los lados menores), siempre y cuando presente cavidad rectangular central en la cara del sillar no visible, circunstancia que determinaría el lecho y sobrelecho del sillar $^{18}$ (Fig. 13).

Hilada $9^{\mathrm{a}}$. Arquitrabe (Figs. 15 y 16)

Perteneciente a esta hilada únicamente tenemos una pieza: el denominado sillar $n^{\circ} 15$, con una altura de $0,59 \mathrm{~m}$. Se trata de un fragmento moldurado de arquitrabe del entablamento al que corresponde esta hilada (Abad y Bendala, 1985, 162, fig. 19; Abad, 2011, 211, fig. 14).

\section{Hilada $10^{\mathrm{a}}$. Friso (Figs. 15 y 16)}

La $10^{\mathrm{a}}$ hilada corresponde al friso del monumento. En ella hemos ubicado dos de los sillares estudiados, concretamente el $n^{\circ} 3$ y el no 4 . Ambos presentan una altura de $0,67 \mathrm{~m}$, constituyen un paramento trabajado liso y su profundidad no permite ubicarlos en las hiladas inferiores por el menor espacio existente entre la línea exterior de lienzo y la bóveda interior. Asimismo, la

18. En el caso de no presentar cavidad rectangular central el sillar podría ubicarse también en la sexta o séptima hilada del monumento.

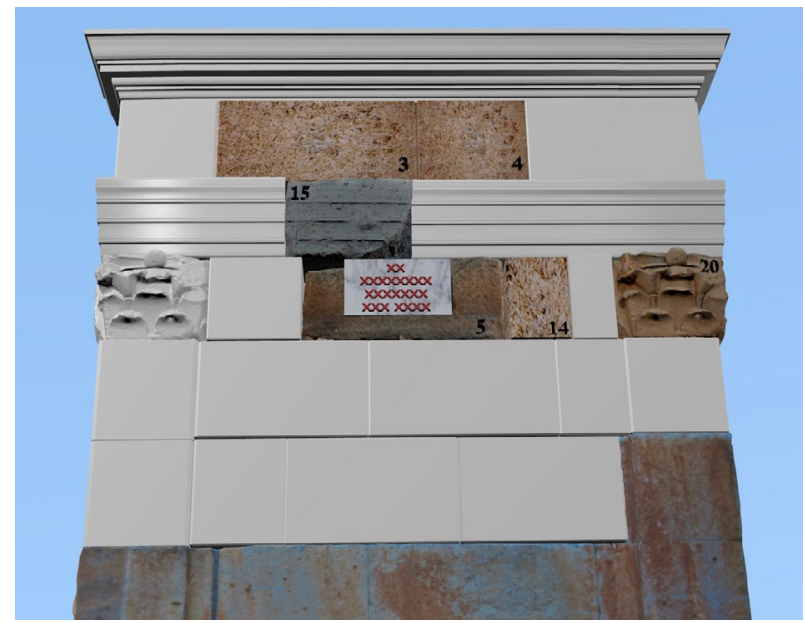

Figura 14: Recreación virtual hipotética de la posible placa con inscripción del monumento vista desde la perspectiva a pie de torre.

altura de estos sillares ubicados en el friso hace que el entablamento -incluidos arquitrabe y cornisa- alcance los 6 pies romanos.

Destaca la presencia en el sillar $n^{0} 3$ de dos surcos de sección en $\mathrm{V}$, cuya función era alojar una palanca para el desplazamiento horizontal de los sillares de la fila superior (Adam 1989, 55, fig. 119), que en este caso correspondería a la cornisa. Estos agujeros de pinzas se tallaban en el sobrelecho de los sillares que ya estaban colocados en el momento de la maniobra (Adam, 1989, 55), lo que en el caso del sillar $\mathrm{n}^{\mathbf{0}} 3$, corrobora por un lado que la cara donde se encuentra el agujero de pinza es el sobrelecho, y por otro indica que el sillar llegó a formar parte de una hilada que se utilizó de apoyo para el desplazamiento de la hilada superior, en este caso la de la cornisa (Fig. 9).

\section{Hilada $11^{\mathrm{a}}$. Cornisa (Figs. 15 y 17)}

Esta última hilada constituye la línea de cornisa del entablamento. A ella pertenecen el sillar $\mathrm{n}^{\circ} 17$ (ya estudiado por Abad y Bendala), los sillares $\mathrm{n}^{\mathrm{o}} 11 \mathrm{y} \mathrm{n}^{\mathrm{o}} 25$, localizados en el 2008 y los sillares $n^{\circ} 22$ y n $^{\circ} 24$, documentados en la campaña actualmente en curso (Fig. 4), ya que todos presentan las mismas molduras ornamentales. Hay que destacar el sillar $n^{\circ} 25$ hallado en el interior del conditorium, que a pesar de sus reducidas dimensiones presenta dos de sus caras molduradas y por tanto pertenece a un fragmento de la esquina de la cornisa del monumento.

Además, el estudio de los sillares $\mathrm{n}^{\mathrm{0}} 11, \mathrm{n}^{\mathrm{o}} 17 \mathrm{y}$ $\mathrm{n}^{\circ} 22$ ha permitido constatar la presencia de marcas denominadas mortajas con forma de cola de milano en los laterales no moldurados del sobrelecho. La función de estas mortajas era la de prevenir las aperturas de las juntas entre los sillares mediante la inserción en estas huellas de una pieza de metal (grapa) que unían los sillares en horizontal (Adam 1989, 56). 
Hilada $9^{a}$

Arquitrabe
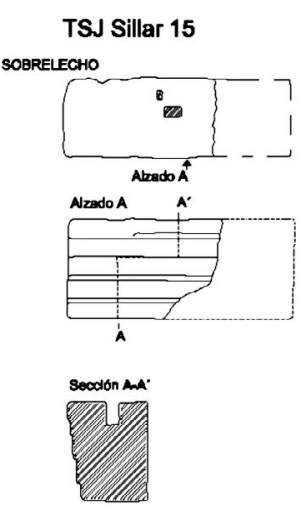

Hilada $10^{\mathrm{a}}$
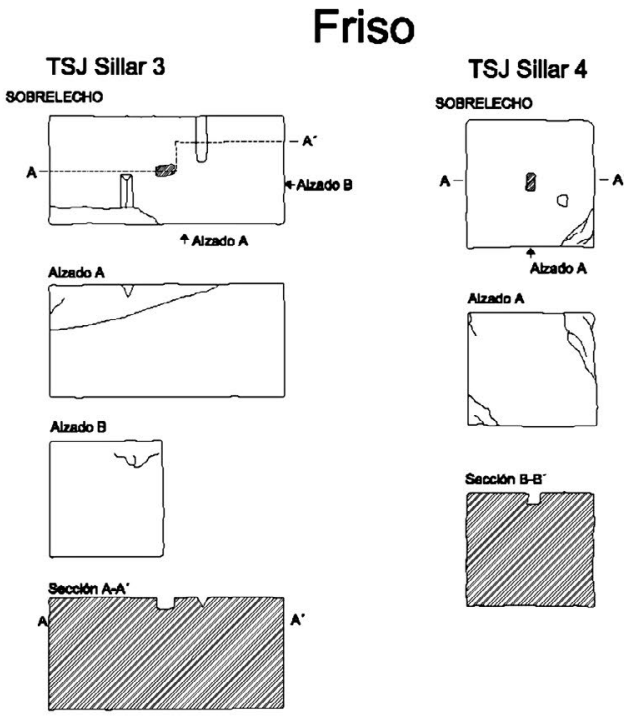

\section{Hilada $11^{a}$}

\section{Cornisa}
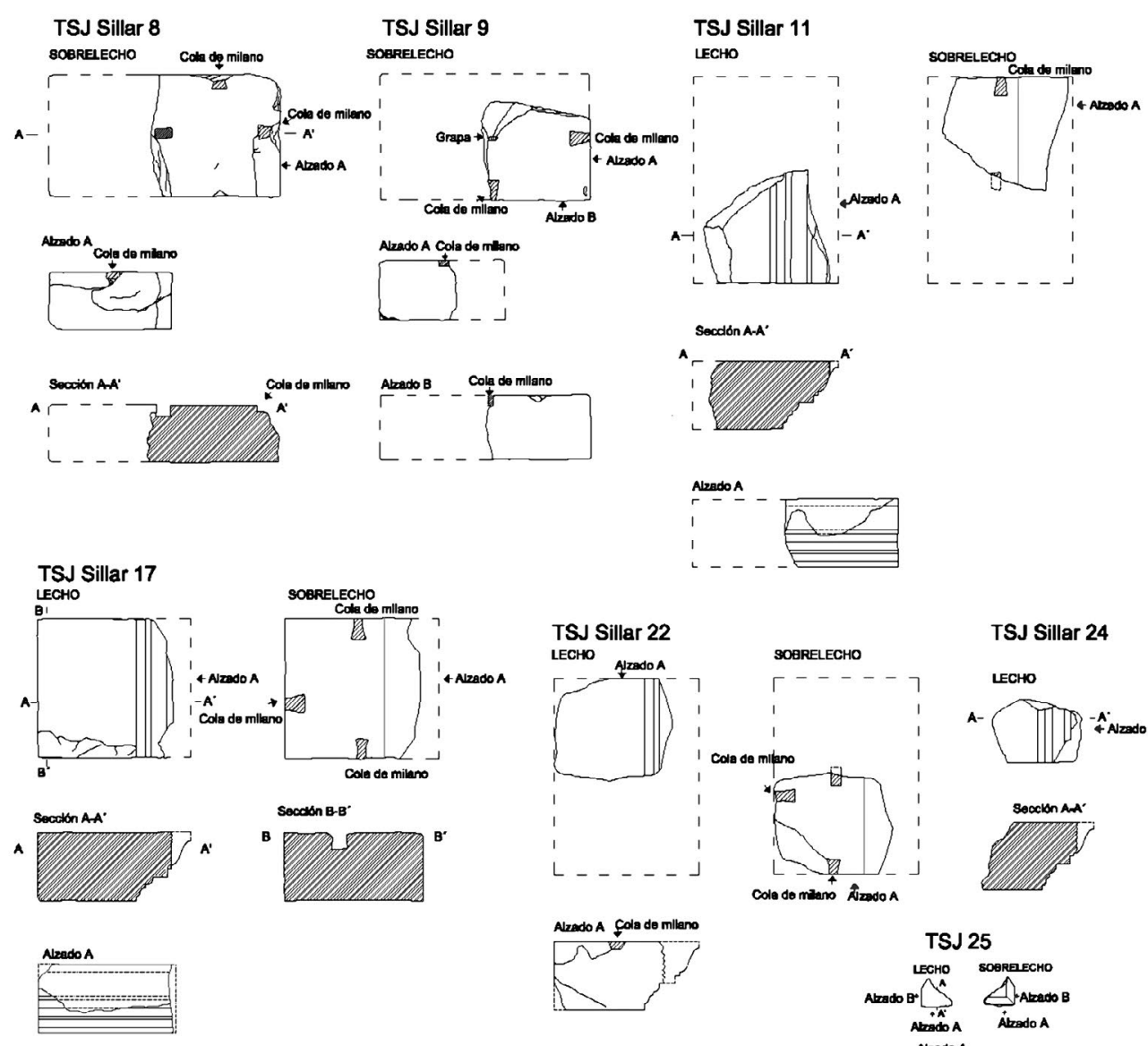

TSJ Sillar 24
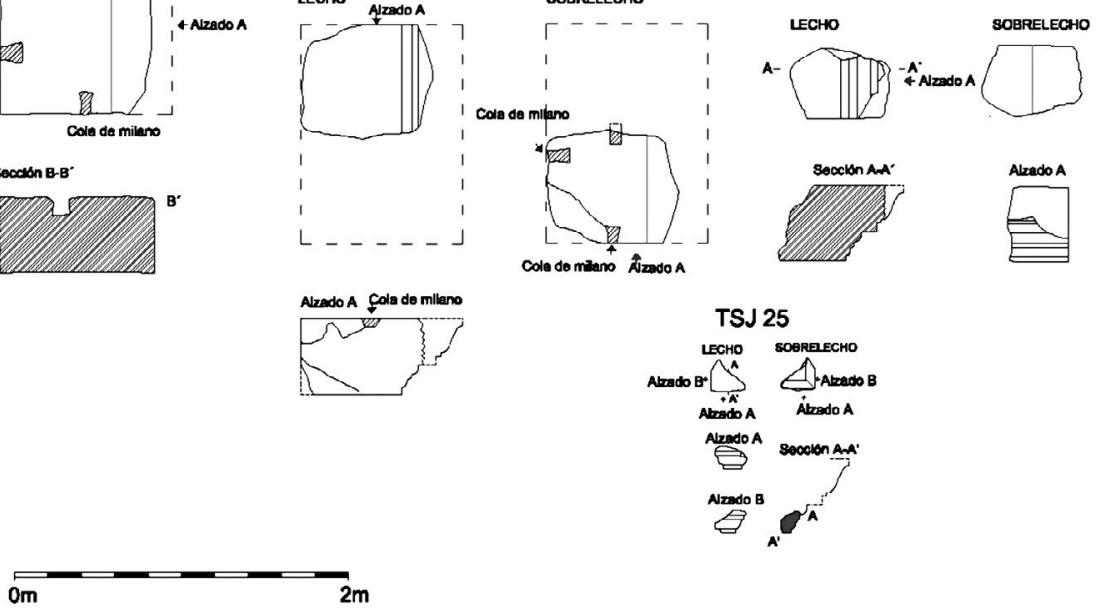

Figura 15: Dibujo sillares ubicados en las hiladas $9^{\mathrm{a}}, 10^{\mathrm{a}}$ y $11^{\mathrm{a}}$. 

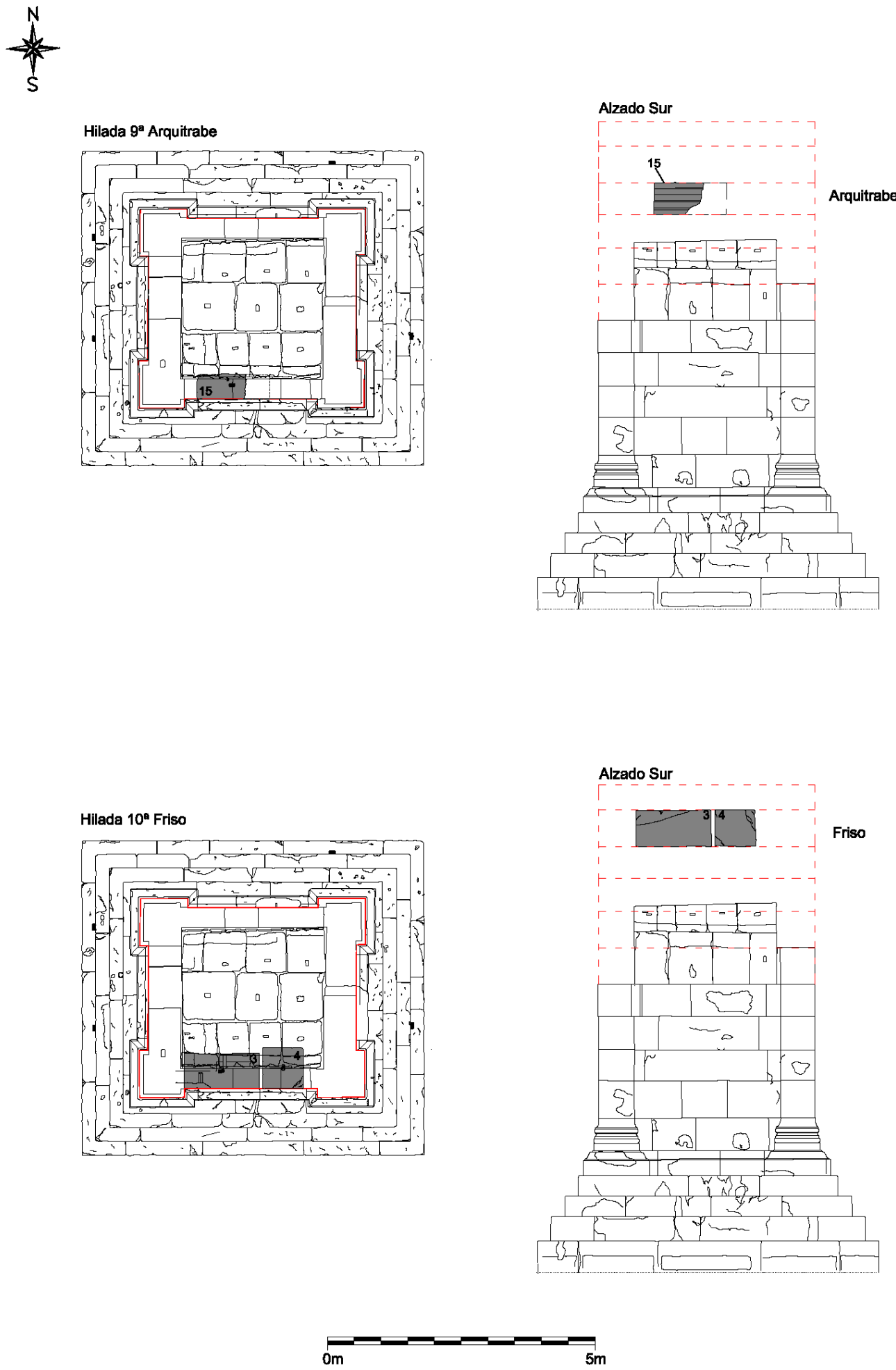

Figura 16: Ubicación hipotética de los sillares documentados en las hiladas $9^{\mathrm{a}}$ y $10^{\mathrm{a}}$ (arquitrabe y friso).

Asimismo, se han localizado dos sillares $\left(n^{\circ} 8\right.$ y $n^{\circ}$ 9) que presentan también estas mortajas en forma de cola de milano en los laterales. Este hecho nos lleva a pensar que dichos sillares estarían unidos entre sí y a su vez con los sillares de cornisa moldurados a modo de cubierta, por lo que constituirían el cierre del monumento a línea de cornisa (Fig. 17). Las piezas de metal que unirían los sillares de esta línea servirían para dar solidez a la cubierta de la torre, como base para asentar el posible pyramidium.

Pensamos que la cubierta, constituida por los sillares anteriormente citados, apoyaría sobre un relleno 


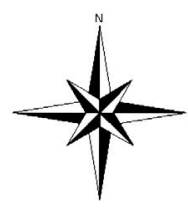

Hilada $11^{a}$ Cornisa

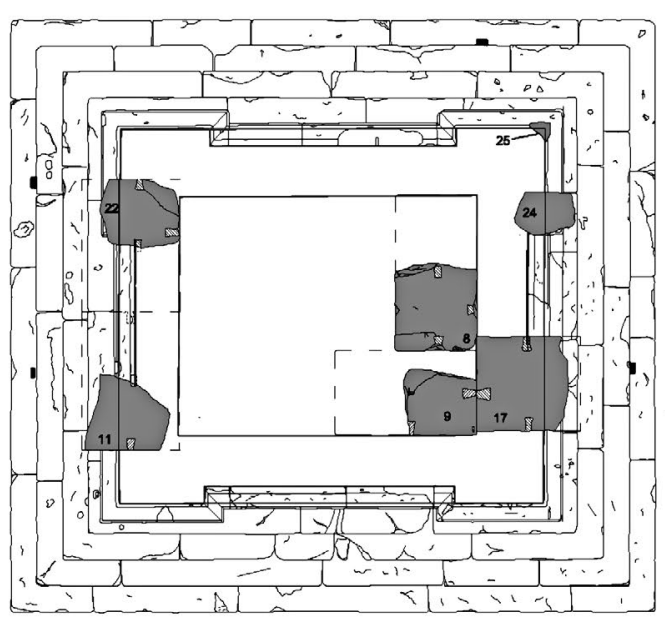

Alzado Norte
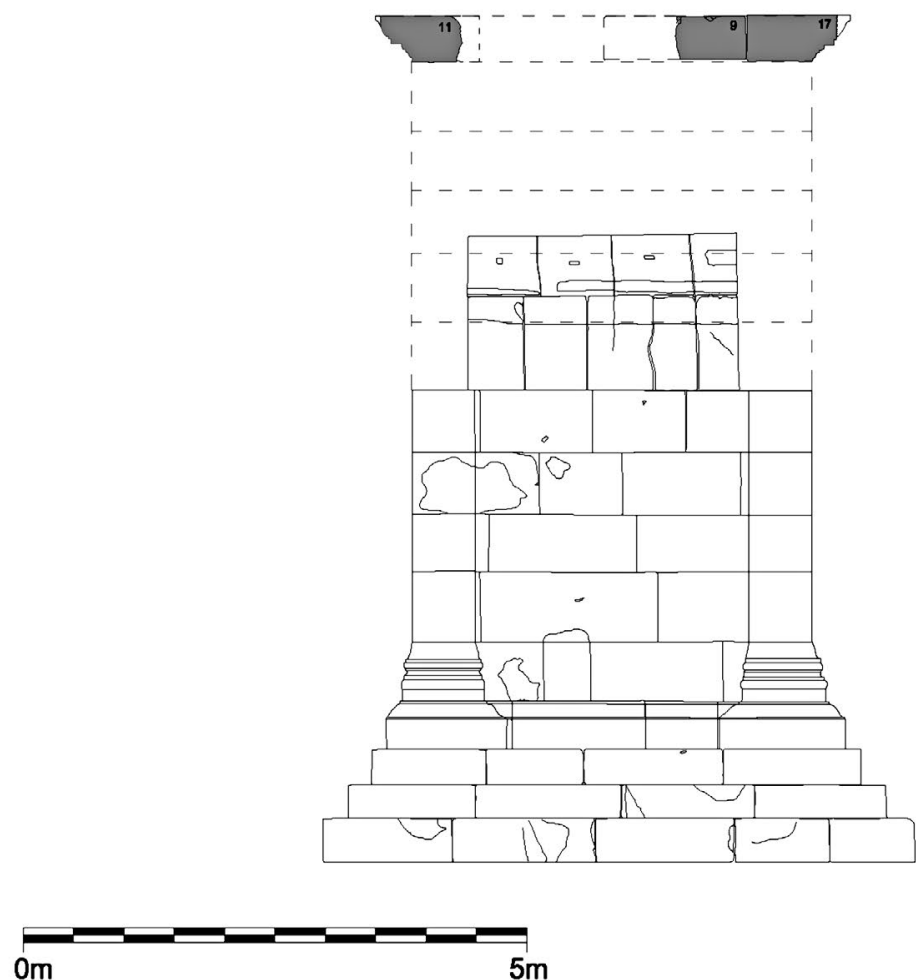

Figura 17: Ubicación hipotética de los sillares documentados en la hilada $11^{\text {a }}$ (cornisa).

intencional de materiales ligeros que colmataría el espacio entre la superficie de la bóveda, la línea interior del entablamento y la propia cubierta, como propone Cid Priego en la Torre de Breny (Cid Priego, 1950, 43). Tanto un relleno de sillares como uno de caementicium supondría una presión estructural innecesaria sobre la bóveda que además habría dejado evidencias, bien en forma de sillares que se adaptaran a este espacio, bien en forma de restos de caementicium sobre la superficie de la bóveda conservada, inexistentes en nuestro caso.

Finalmente hemos de destacar también la presencia en el sillar $n^{\circ} 9$ (sillar de cubierta) de una hendidura en forma de media luna, pensamos que usada para alojar una palanca para el desplazamiento horizontal de los sillares de la fila superior, lo que indica la existencia inequívoca de una coronación del edificio (pyramidium) (Fig. 9).

\section{Pyramidium}

No existen elementos arquitectónicos hasta el momento que puedan pertenecer al pyramidium del monumento. Sin embargo, esta hipótesis de coronación es del todo 


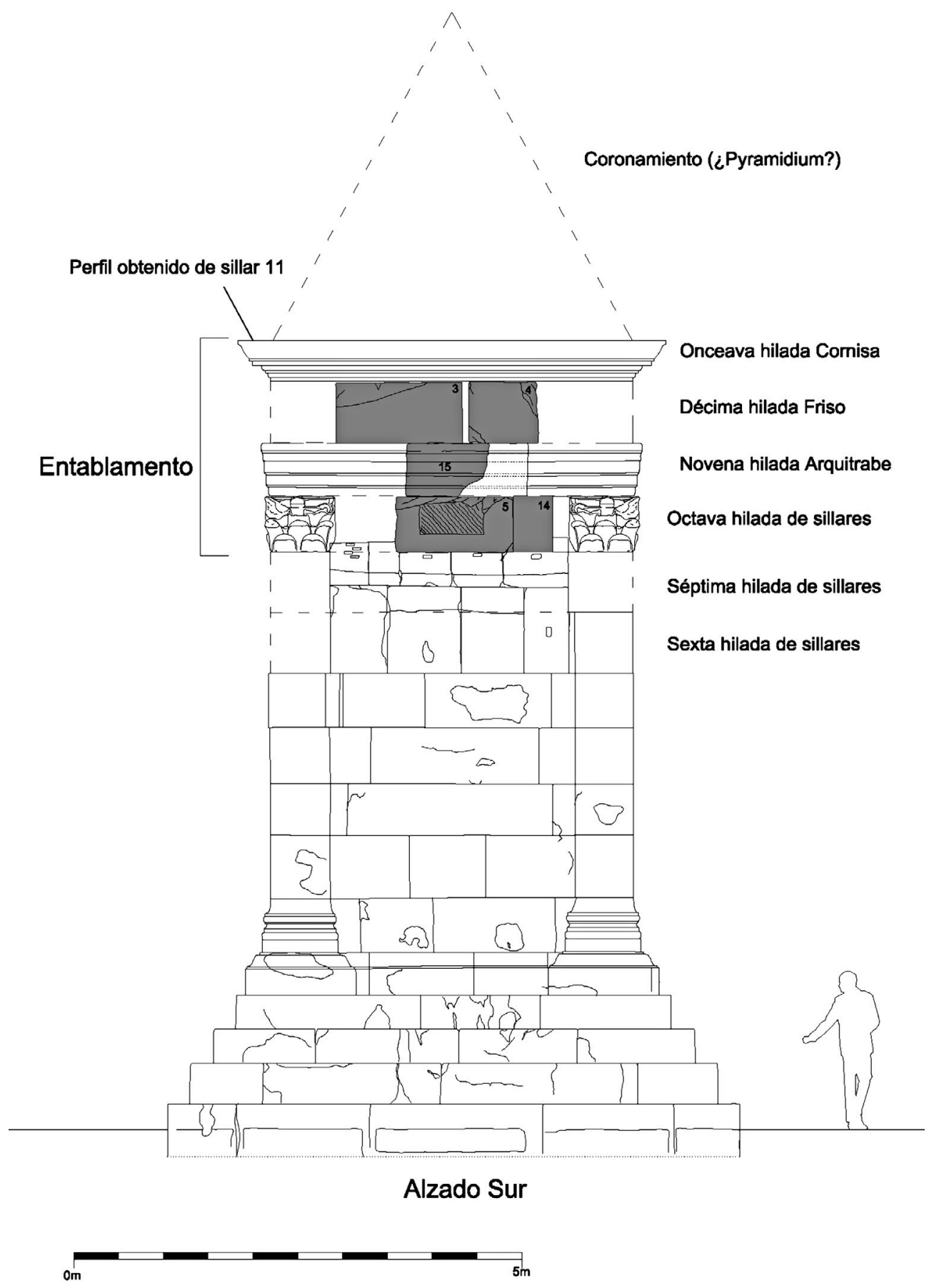

Figura 18: Reconstrucción ideal del alzado sur con los sillares originales ubicados.

plausible si tenemos en cuenta la tipología y metrología del edificio a la que hemos aludido anteriormente (Fig. 18). Coronamientos de este tipo los encontramos en los monumentos norteafricanos ya citados como los de Akbou o de Maktar (Romanelli, 1970; Prados Martínez, 2008, 287, fig. 317); y en cuanto a monumentos hispanos tenemos el monumento del Hornillo de Santa Catalina de Baelo Claudia que conserva restos indudables de un primitivo remate piramidal, o el monumento de Alcalá la Real en Jaén que conserva la cubierta piramidal de ocho escalones en el exterior (Ruiz Osuna, 2008, 291); y también numerosas propuestas de reconstrucción de monumentos turriformes o de edícula sobre pódium, como la Torre de Vilablareix donde Sanmartí propone una cubierta piramidal (Sanmartí, 1984, 126), la Torre de los Escipiones donde Hauschild ${ }^{19}$,

19. Theodor Hauschild propone la existencia de pyramidium en la Torre de los Escipiones por paralelos norteafricanos y por la transición de una planta rectangular en el zócalo y primer cuerpo del monumento a una planta cuadrada en el segundo cuerpo, sobre la que se adaptaría perfectamente un coronamiento piramidal. 
TSJ Sillar 10

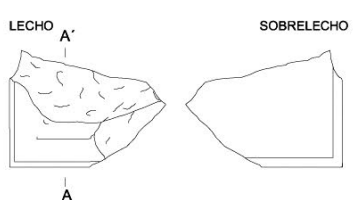

Sección A-A

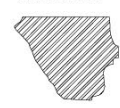

TSJ 26

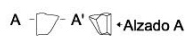

Alzado
TSJ Sillar 23

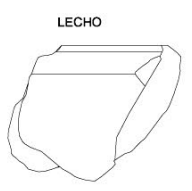

Sección A-A
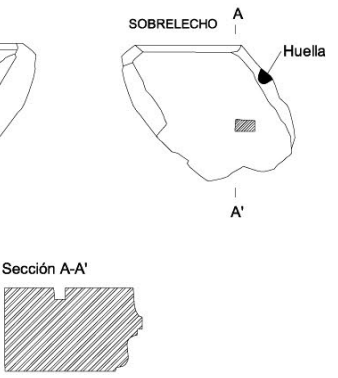

RESTITUCIÓN HIPOTÉTICA DE CORONAMIENTO

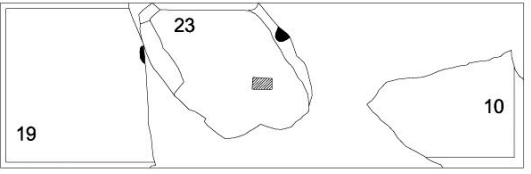

Om - - - $-2 \mathrm{~m}$
TSJ Sillar 19

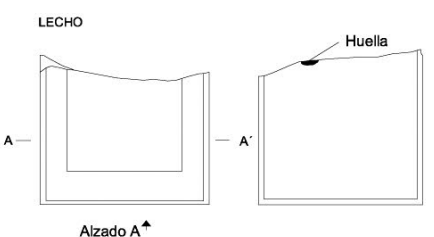

Sección A-A'

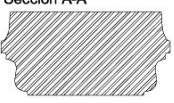

Alzado A

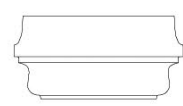

ARA ANEPIGRÁFICA
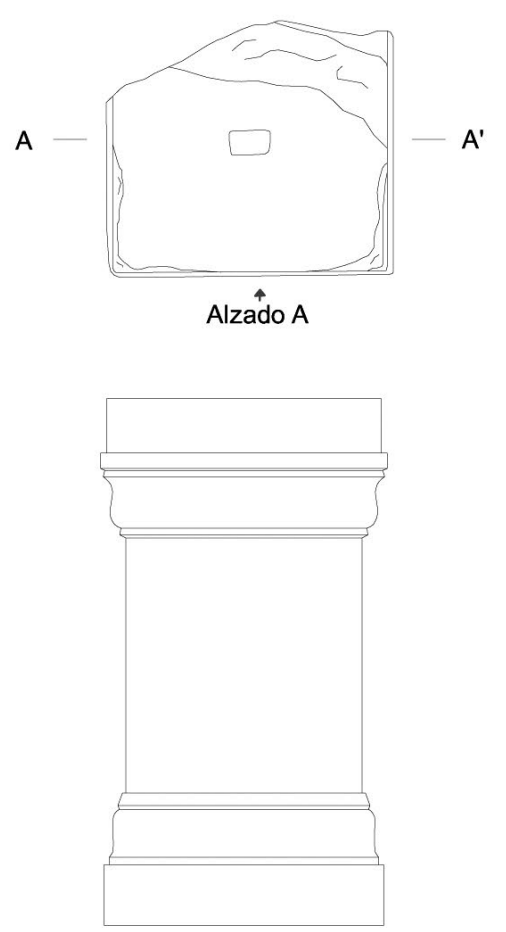

A

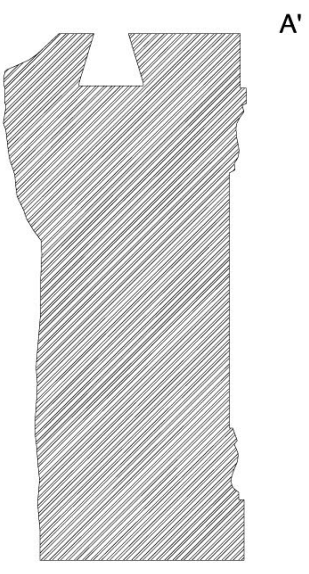

Alzado A

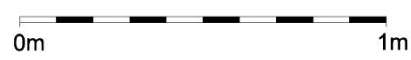

Figura 19: Dibujo de las piezas arquitectónicas no ubicadas en el monumento. 
Sanmartí o Cancela proponen un pyramidium de lados rectos (Hauschild, 1966, 174, fig. 12; Sanmartí, 1984, 124; Cancela, 2002, 177) o la Torre del Cincho de $B a$ silippo donde Rodríguez Hidalgo se inclina por una cubierta en forma de pyramidium (Rodríguez Hidalgo, 1979-80, 432).

\section{ELEMENTOS ARQUITECTÓNICOS NO UBI- CADOS EN EL MONUMENTO}

Finalmente, además de los sillares documentados que se pudieron adscribir al monumento, existen un total de 9 piezas de ubicación desconocida. Entre ellas destacan tres piezas molduradas $\left(\mathrm{n}^{\circ} 10,19\right.$, y 23) más o menos completas que pertenecen a un mismo tipo de moldura consistente en una cyma recta entre filetes y rematada por una moldura plana sobre la que asienta un ancho remate de caras oblicuas.

Pensamos que estas piezas molduradas podrían ser las partes del coronamiento de un pedestal destinado a sostener una estatua. La relación entre estas piezas la establecen por un lado el tipo de moldura idéntico que aparece en los cuatro elementos en mayor o menor medida y por otro lado una misma anchura existente en las dos piezas mejor conservadas. El sillar $n^{\circ} 19$, que presenta la moldura completa en tres de sus lados (por lo tanto destinado a ser visto exento), tiene una anchura de $90 \mathrm{~cm}$, medida que coincide con la del sillar $\mathrm{n}^{\circ} 23$, que al presentar una cavidad rectangular central nos ha permitido establecer la anchura original de la pieza.

A juzgar por estos datos pensamos que las tres piezas pueden ser partes de un mismo elemento rectangular que funcionaría a modo de coronamiento, en el que la cavidad rectangular central del sillar $\mathrm{n}^{\circ} 23$ marcaría el sobrelecho o cara superior de este remate de pedestal. En la parte superior de este coronamiento formado por estos tres sillares, la cavidad rectangular central no es la única huella presente, ya que tanto el sillar $\mathrm{n}^{\mathrm{o}} 19$ como el $\mathrm{n}^{\mathrm{o}} 23$ presentan parte de dos orificios semicirculares que podrían estar destinados a acoger el anclaje de esculturas (Fig. 19).

Encontramos un paralelo de este tipo de coronamiento de pedestal -aunque menos austero que el nuestro- en el pedestal honorífico dedicado a la familia Calventia del foro de Segobriga con huellas similares a las nuestras para el anclaje de esculturas (Abascal, Alföldy y Cebrián 2011, 75-78).

Asimismo, existen también paralelos dentro de contextos funerarios: el pedestal dedicado a $C$. Furnius Fortunatus $\left(C I L, \mathrm{II}^{2} / 7,306\right)$ que presenta un coronamiento muy similar al nuestro pero con la parte posterior alisada, el dedicado a T. Flavius Antoninus (CIL, $\left.\mathrm{II}^{2} / 7,290\right)$, el de L. Aelius Faustinus (CIL, $\mathrm{II}^{2} / 7$, 302) todos de Córdoba, o la inscripción honorífica post mortem dedicada a M. Iulius Hermesianus de Astigi (Écija) $\left(C I L, \mathrm{I}^{2} / 5,1180\right)$; aunque su ubicación original es desconocida, hay indicios de su pertenencia a terrenos de índole funeraria (Ruiz Osuna, 2008, 113-115).

En conclusión, pensamos que estas piezas serían parte de un pedestal honorífico que estaría situado en el entorno del monumento. Podría tratarse de un homenaje póstumo a un personaje del municipium romano de Villajoyosa, distinguido mediante estatuas, medio de representación habitual de las élites locales. Aunque no se han recuperado restos de esculturas en las intervenciones realizadas hasta el momento, contamos con las citas tanto de Antonio de Valcárcel a finales siglo XVIII como de Ceán Bermúdez en 1832 que nos hablan de la presencia de restos escultóricos en las inmediaciones del monumento, datos por tanto que podrían apoyar nuestra propuesta.

Finalmente, el conjunto de piezas no pertenecientes al monumento se completa con un ara anepígrafa, hoy a los pies de la torre, que se localizó durante unas labores de canalización de la zona cercana a la misma. Se trata, como hemos dicho, de un pedestal con una cavidad rectangular central en el sobrelecho, cuerpo central prismático enmarcado entre filetes y molduras de talón que apoyan sobre plinto liso (Abad y Bendala, 1985, 161) (Fig. 19).

\section{EL MONUMENTO Y SU CONTEXTO}

Los descubrimientos llevados a cabo en la última década en el casco urbano de La Vila, derivados del desarrollo urbanístico de la ciudad, culminaron con la localización en el año 2006 de las termas monumentales romanas del municipium de Villajoyosa, lo que permitió ubicar la ciudad romana en el subsuelo de su actual casco urbano, a $3,3 \mathrm{~km}$ al oeste del monumento funerario de la Torre de Sant Josep (Espinosa, RuizAlcalde y Marcos, 2011; Ruiz-Alcalde, 2010).

Asimismo, entre 1995 y 2003 se excavaron diversos sectores de dos grandes necrópolis dentro del actual casco urbano, Les Casetes y Poble Nou, asociadas a las calzadas de entrada a la urbs. Si bien las fases mejor conservadas pertenecen a época ibérica, se documentaron también algunas de época romana que, tras la localización de la ciudad en el 2006, se pudieron interpretar como las necrópolis urbanas del municipium. Dichas áreas funerarias aparecían asociadas a los caminos de entrada a la ciudad desde el oeste y el norte. En el año 2005 y en el 2009, durante la excavación de las villas romanas altoimperiales del El Xarquet (Marcos, 2010) y de Barberes Sud, también en el actual casco urbano de Villajoyosa, se pudieron documentar los restos de la tercera vía de entrada a la urbs que conectaba la ciudad romana de La Vila con las ensenadas de Benidorm y Altea. Esta tercera vía, en dirección al este, pensamos que sigue la línea de la actual N-332 aunque con un pequeño desvío hacia el norte a la altura del río Torres para 
vadearlo $^{20}$, por lo que pasa a unos $1.200 \mathrm{~m}$ al norte del monumento funerario (Fig. 1).

Nos encontramos pues no ante un enterramiento monumental realizado en el contexto de una necrópolis urbana sino ante una sepultura realizada dentro de un fundus privado que pensamos acogería la tumba del propietario y posiblemente de los servi que allí vivían $\mathrm{y}$ trabajaban. No se han encontrado hasta el momento restos de enterramientos de adultos en los alrededores de la torre, pero sí los del ya citado enterramiento infantil de datación incierta por las razones explicadas en un apartado anterior. Sin embargo, la certeza de que el área asociada a la torre poseía un cierto carácter sagrado y el hábito en el mundo romano de enterrarse cerca de sepulcros de cierta envergadura, apoyan la posible adscripción cronológica romana de este enterramiento, pudiendo tratarse de un hijo de un miembro de la familia de los propietarios del fundus o de uno sus servi.

Aunque las nuevas obras de urbanización del área donde se encuentra la torre han modificado algo el paisaje, los sondeos y excavaciones en la zona atestiguan que el monumento se encontraba en una posición privilegiada; sobre la cima de una elevación pronunciada del terreno muy próxima a la playa del Torres y a la desembocadura del río del mismo nombre, lugar donde probablemente existía un fondeadero natural en la antigüedad. La localización del monumento, en un lugar tan visible desde el mar, nos lleva a pensar que su fachada principal estaría orientada hacia la vía de comunicación marítima.

A pesar de la cercanía de la vía terrestre anteriormente citada, a la que nuestra torre estaría conectada mediante un camino secundario, pensamos que el monumento estaría concebido para su contemplación desde la vía marítima, en la que el tránsito era especialmente abundante durante el alto imperio (momento en el que se erige el monumento), tal y como lo atestiguan las diferentes prospecciones subacuáticas realizadas hasta el momento o la excavación del pecio del Bou Ferrer (Espinosa, Castillo y Lara, 2011; De Juan, Cibecchini y Vento, 2011). La ubicación en un altozano muy cercano al mar, punto estratégico y privilegiado como es nuestro caso, es la elegida por los grandes prohombres con el fin de que el recuerdo del difunto quedara en la mente de los que divisaran el

20. Los restos de calzada localizados más al este de la urbs son los de Barberes Sud, que siguen aproximadamente el mismo trazado que el camino real de época moderna, por lo que pensamos que a priori la calzada romana transcurriría siguiendo este trazado, que a la altura del río Torres dibuja una curva hacia el norte para vadear la cuenca fluvial. En esta zona de paso se conserva en la actualidad el llamado Pont del Torres, fechado en el siglo XVIII, que fosiliza el camino de época moderna y además, muy cerca de este, tenemos los restos de un gran aljibe romano (Olcina, 2011, 294) por lo que es posible que el camino real esté fosilizando la antigua calzada romana. monumento desde el mar, garantizando así la perennitas del fallecido por cuanto la única manera de pervivir dentro de la mentalidad romana era que alguien te recordase. Esta costumbre queda patente ya desde el siglo I a.C. en la tumba de Munacio Planco (15 a.C.), ubicada en lo más alto de uno de los cabos que dominan la bahía de Gaeta en el Lazio, convertida casi en un faro para la navegación, con un control absoluto del territorio (Vaquerizo, 2010, 31).

Además es también hacia el mar hacia donde miraría la posible inscripción de nuestro sepulcro (Fig. 18), dando fuerza a la idea de que la torre se realizó para ser vista desde allí, al igual que ocurre en el monumento del Hornillo de Santa Catalina y en el resto de los sepulcros de tipo itálico de Baelo Claudia, que no aparecen orientados a la calzada cercana sino a la vía marítima y cuyas placas con los tituli sepulcrales de los fallecidos en muchas ocasiones se han hallado en el flanco que daba al mar (Vaquerizo, 2010, 179). Este mismo perfil se observa también en la necrópolis del Porto de Roma Isola Sacra (Ostia, Italia) presidiendo el delta del Tíber (Prados, 2011, 198).

En conclusión, nuestra propuesta es que nos encontramos ante un enterramiento monumental situado en un fundus, es decir una propiedad en el ager, ajeno al núcleo urbano, pero cerca de las vías de comunicación tanto terrestre como marítima; en un tossal privilegiado próximo también a la vía fluvial del río Torres y, por tanto, en un marco escenográfico único para enaltecer al difunto que sin duda gozaba de una posición social destacada.

Monumentos hispanos que comparten algunas de estas características los encontramos en la tumba-templo relacionada con la villa de Liédena (Navarra), situada a $150 \mathrm{~m}$ de la villa en una ubicación privilegiada de clara visibilidad (Cancela, 2002, 167), en el columbario de Vilarrodona que aparece orientado al camino que pasaba junto al fundus (Ruiz Osuna, 2008, 77) o en la Torre de los Escipiones, situada a las afueras de la ciudad de Tarraco y cercana a la Vía Augusta por citar algunos ejemplos.

Ya para finalizar tenemos que hacer referencia a la procedencia de los materiales empleados en la construcción del monumento, puesto que los últimos estudios desarrollados en Villajoyosa han permitido la localización de la cantera de donde pensamos proceden los sillares empleados en la erección del sepulcro. Se encuentra situada a unos $1800 \mathrm{~m}$ al este de la torre (Fig. 1), en el yacimiento denominado Castilla I ( $\mathrm{n}^{\mathrm{o}}$ 79 del Catálogo de Bienes y Espacios Protegidos de Villajoyosa).

Los trabajos realizados hasta el momento en el yacimiento de la cantera, están en fase inicial y serán objeto de una próxima publicación. La cantera se prospectó de manera superficial en la década de los noventa, momento en el que se documentaron materiales en superficie de los siglos I d.C. y II d.C. Un reciente reconocimiento del área permitió la localización de dos frentes de cantera, con la presencia de las huellas 
de las cuñas empleadas para la extracción junto con numerosos sillares, algunos sin terminar de trabajar, dispuestos para su traslado.

Asimismo, se han realizado análisis petrológicos en el Laboratorio de Petrología Aplicada, Unidad Asociada de la Universidad de Alicante al Consejo Superior de Investigaciones Científicas ${ }^{21}$ que han determinado que tanto los materiales pétreos empleados en la torre como las muestras tomadas de la cantera pertenecen a un mismo tipo de piedra caliza con determinados fósiles marinos, denominada concretamente caliza fosilífera con rodolitos y macroforaminiferos del género nummulites.

El uso de piedras locales en el ámbito funerario, como es el caso, acredita el fuerte peso de la tradición por parte de los artesanos especializados y de las élites locales que encargaban la construcción de este tipo de sepulcro (Beltrán, 2002, 244; Vaquerizo, 2010, 118). Este hecho se ve reflejado también en otros monumentos funerarios hispanos de diferente tipología, en la Torre de los Escipiones construida con grandes bloques de piedra calcárea de la cantera cercana de Punta de la Creueta (Gutiérrez García-Moreno, 2009, 167), la Torre Ciega de Cartagena realizada en opus reticulatum de piedra volcánica de la región (Abad, 2003, 92) o la denominada tumba monumental de Segobriga en forma de altar, realizada en caliza local amarillenta extraída de las cercanas canteras de Diana (Cebrián, 2010, 143).

\section{PROYECTO DE RESTAURACIÓN Y DOCU- MENTACIÓN VIRTUAL TRIDIMENSIONAL}

En la actualidad existe un proyecto de restauración y puesta en valor del monumento. Se está llevando a cabo a través de un convenio entre la Conselleria de Cultura y la Sección Municipal de Arqueología, Etnología y Museos de Villajoyosa, dirigido por el Arquitecto de Conselleria de la Unidad de Patrimonio Histórico Artístico de Alicante, Santiago Varela Botella, con la colaboración del Área de Arqueología de la Universidad de Alicante a través del proyecto de investigación «Arqueología romana de Villajoyosa: de la República a la Antigüedad Tardía».

La reconstrucción virtual, a partir del registro fotogramétrico del monumento y de un levantamiento virtual tridimensional a escala de la torre y de la

21. Desde aquí queremos agradecer la ayuda desinteresada prestada en la realización de los análisis petrológicos de $\mathrm{M}^{\mathrm{a}}$ Ángeles García del Cura, Doctora en Petrología, Investigadora del CSIC; de Miguel Louis Cereceda, Doctor en Arquitectura, Catedrático de restauración arquitectónica del Departamento de Construcciones Arquitectónicas de la Universidad de Alicante, y de Yolanda Spairani Berrio, Arquitecta Técnica, Profesora titular del Departamento de Construcciones Arquitectónicas de la Universidad de Alicante.

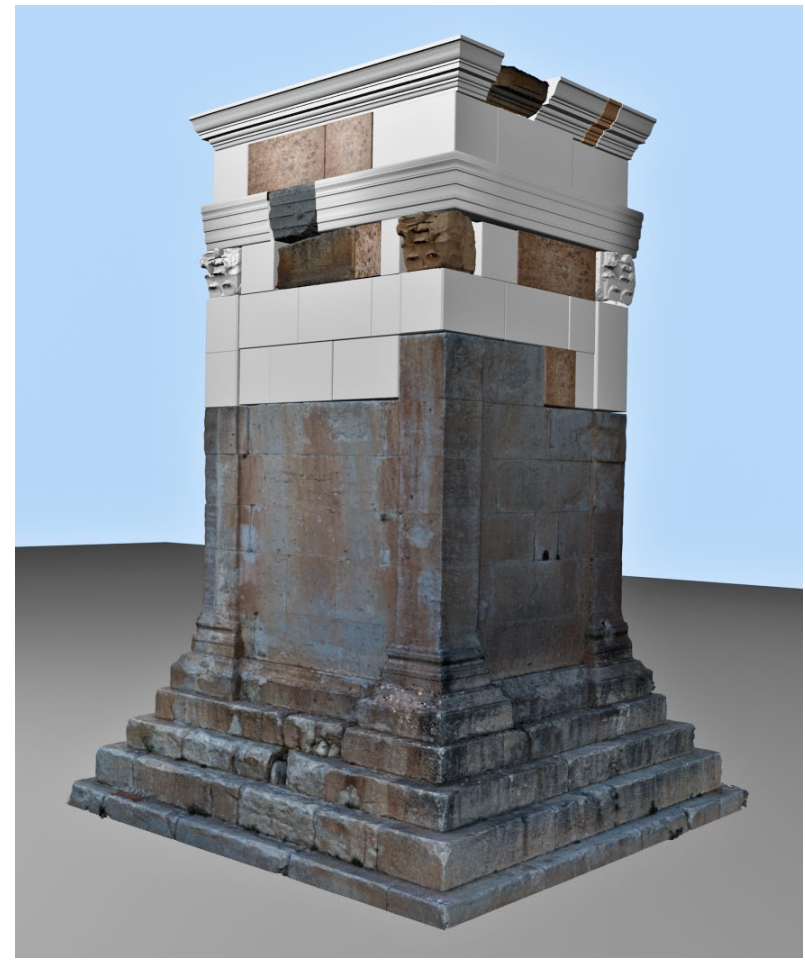

Figura 20: Anastilosis virtual del monumento.

mayoría de sus elementos arquitectónicos (Fig. 20), han permitido crear una documentación lo suficientemente precisa que sirva de base a una propuesta de reconstrucción virtual a escala del monumento romano sobre la que se ha planificado en detalle el proyecto de restauración.

Como la próxima restauración del monumento conllevará el cierre reversible del interior de la torre, y por tanto, la inaccesibilidad a su interior, se ha realizado una documentación fotogramétrica de los lienzos interiores y de la cara interna de la bóveda (Fig. 7) (Buill, 2007). Esta documentación métrica y de base fotográfica ha posibilitado el estudio de sus paramentos interiores y de su estructura constructiva.

La documentación interior y exterior ${ }^{22}$ se utilizará como base para una recreación infográfica que a modo de complemento divulgativo muestre no sólo los pasos y modus operandi de la construcción del monumento en época romana, sino también el estado de la torre antes de su restauración y el proceso virtual de restitución de la parte superior de la misma.

Este proyecto es la culminación de la serie de trabajos y proyectos anteriores a los que hemos hecho referencia y que compartían el mismo objetivo: la

22. Los trabajos de documentación fotogramétrica han sido realizados por Ana María Charquero Ballester, coautora de este artículo, dentro del marco de una ayuda a la investigación concedida por Instituto Alicantino de Cultura Juan Gil-Albert en 2012. 


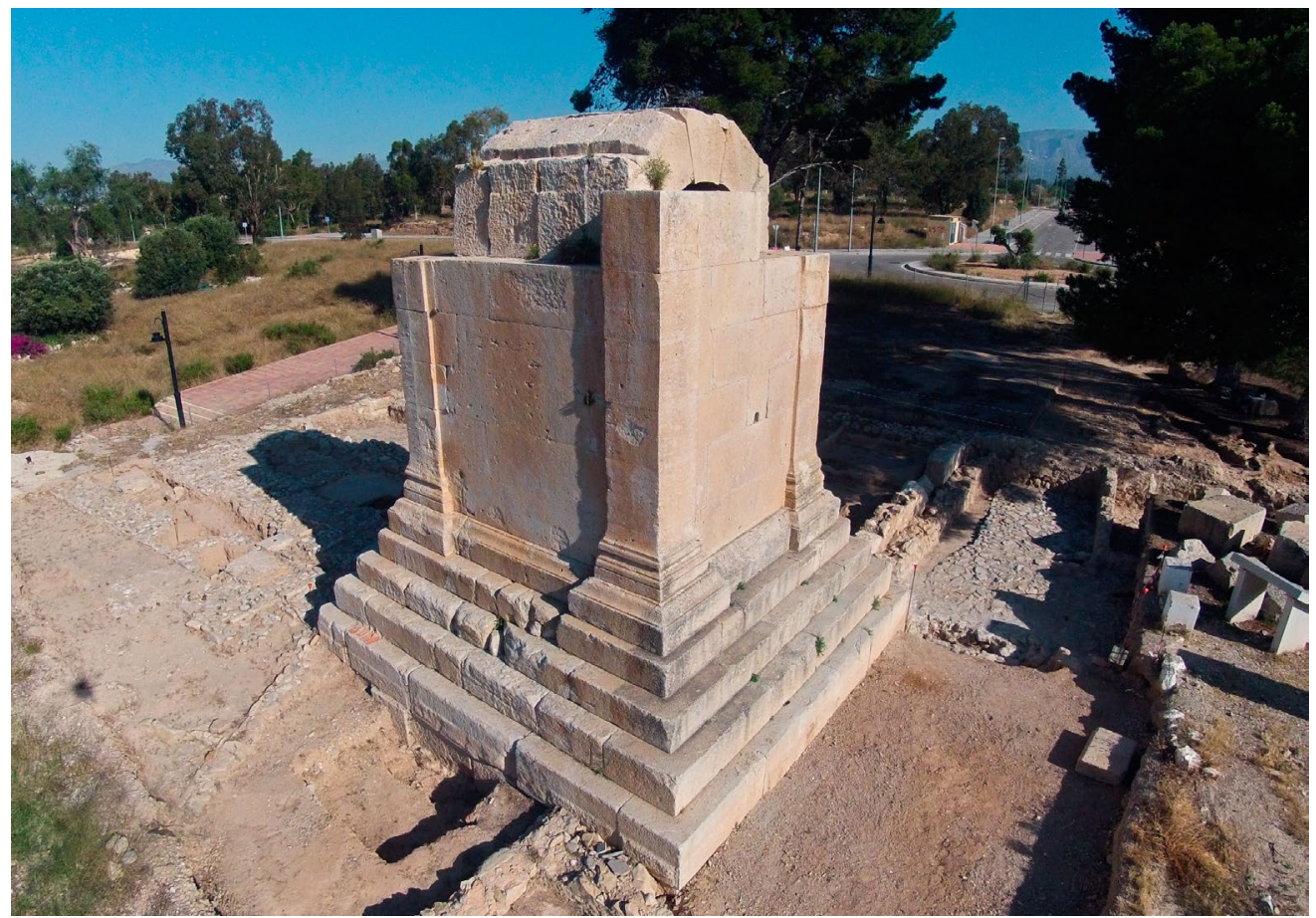

Figura 21: Estado actual del monumento.

puesta en valor del monumento, para convertirlo en un elemento visitable y un hito del patrimonio cultural de la Comunidad Valenciana. No en vano se trata de uno de los monumentos turriformes romanos mejor conservados de toda Hispania (Fig. 21).

\section{ANEXO}

Durante la campaña de excavación realizada en la primera mitad del año 2014 en los terrenos adyacentes al monumento se han descubierto datos nuevos y relevantes que incluimos como complemento al trabajo realizado. Sin embargo no se agota el tema, ya que la intervención arqueológica aún no ha concluido.

Los nuevos elementos que podemos enmarcar en época romana y coetáneos al monumento, como posteriormente explicaremos, corresponden a una estructura muraria de grandes dimensiones (MR 213) y a una pequeña cubeta (UE 331), realizadas ambas en opus caementicium (Fig. 22 y 23 ).

El muro romano, reutilizado en época moderna, forma una $\mathrm{L}$ en dirección $\mathrm{N}-\mathrm{S} / \mathrm{E}-\mathrm{O}$ con una longitud máxima conocida de $13 \mathrm{~m} \mathrm{~N}-\mathrm{S}$ y de $18 \mathrm{~m}$ E-O, rodeando el flanco norte y oeste del monumento funerario. Presenta una cimentación de mampostería irregular trabada con argamasa con una anchura $58 / 62 \mathrm{~cm}$. Sobre esta se erige un alzado de $50 \mathrm{~cm}$ de ancho realizado mediante encofrado romano, conservado en el área noreste de la excavación y en un punto al oeste del monumento (Fig. 22).

Como se ha comentado con anterioridad, la Torre de Sant Josep se encuentra situada en un tossal amesetado, con pendiente en descenso más pronunciada en el flanco oriental del monumento, donde existía una rambla que discurría en dirección norte-sur.

Pensamos que este hecho explica la localización de una rebaba en forma de cuarto de bocel, también en caementicium, que forma parte del paramento de la estructura muraria y se conserva en el flanco norte del muro al noroeste de la Torre (Fig. 22); apoyaba directamente sobre el nivel geológico. La pendiente en descenso del terreno en esta zona obliga a adaptar las cimentaciones de la estructura muraria al nivel geológico más alto en el área septentrional. De esta forma se evita la erosión derivada de las escorrentías de la rambla anteriormente citada.

Junto al muro, a la altura donde se conserva la rebaba, localizamos una cubeta realizada con lajas de piedras y fragmentos hincados de dolia trabados con argamasa (Fig. 22 y 23). La cubeta, de tendencia rectangular y con unas dimensiones de $1.20 \times 0.90 \mathrm{~m}$, cortaba directamente el nivel geológico y no presentaba ningún tipo de revestimiento hidráulico interno, lo que nos lleva a pensar que podría haberse utilizado como una artesa para amasar el caementicium empleado en los cimientos de la Torre y en el propio muro, siendo arrasada tras su uso.

Tanto la estructura muraria como la cubeta se sitúan cronológicamente en la segunda mitad del siglo II d.C. por los materiales que aparecen, tanto en los estratos que cubren la rebaba de la estructura muraria como en los que colmatan la cubeta, siendo por tanto posteriores a la realización de ambas. Estos niveles presentan fragmentos de T.S.Clara A, concretamente una Hayes 26, TSH y cerámica pintada de tradición ibérica; materiales que nos llevan a un periodo inmediatamente posterior al año 150 d.C. Por tanto, nos 


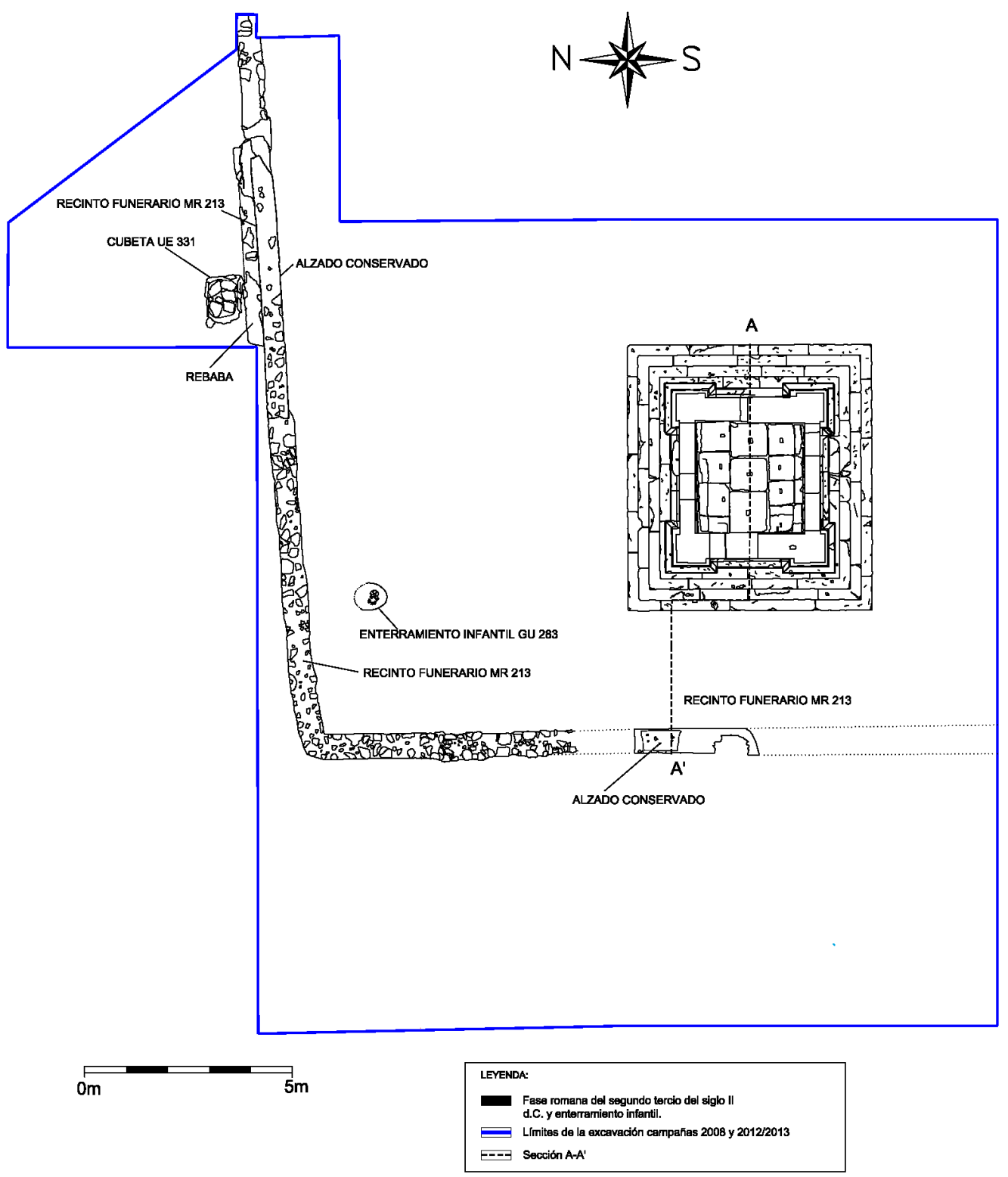

Figura 22: Planimetría, fase romana y enterramiento infantil de la Torre de Sant Josep y su entorno.

parece plausible pensar que la construcción de ambas estructuras sería coetánea a la edificación del monumento funerario, fechado en el segundo tercio del siglo II d.C.

La tipología y la datación de la estructura muraria permiten interpretarla como un recinto funerario que rodeaba (por los datos que tenemos en la actualidad) al menos el flanco norte y oeste del mismo.

La realización de recintos funerarios constituye una práctica muy extendida en Hispania, sobre todo en la provincia Baetica, desde época tardorrepublicana, aunque con mayor desarrollo en el alto imperio, como es el caso.

Estas estructuras son habituales en contextos funerarios de este tipo y presentan una variada técnica constructiva; sillares en los recintos de los monumentos hipogeicos del Palacio de la Merced y de la C/ Bodega s/n en la Colonia Patricia Corduba (Vaquerizo, 2001b, 138-141) o en el muro adosado al monumento funerario septentrional de Edeta (Aranegui, 1995, 199); opus concretum en el recinto que encierra el monumento de «El Castellet» en Ampurias (Almagro, 1951, 3); mampostería irregular trabada con arcilla sobre cimentación de cantos rodados en el recinto localizado en la C/Vía Nova en Asturica Augusta (González et alli, 2003, 305); у opus latericium en la necrópolis de Baelo Claudia (Vaquerizo, 2002b, 202). Nuestro ejemplo (encofrado romano y mampuestos) es menos frecuente, aunque encontramos un paralelo hispano en el denominado Recinto $\mathrm{J}$ del conjunto funerario de «Camino Viejo de Almodovar» de Córdoba (Ruiz Osuna, 2008, 159).

Pensamos que nuestro recinto no sería demasiado alto, para no entorpecer la contemplación del monumento, y tampoco presentaría ornamentación, para no restar protagonismo al sepulcro, entrando dentro de 


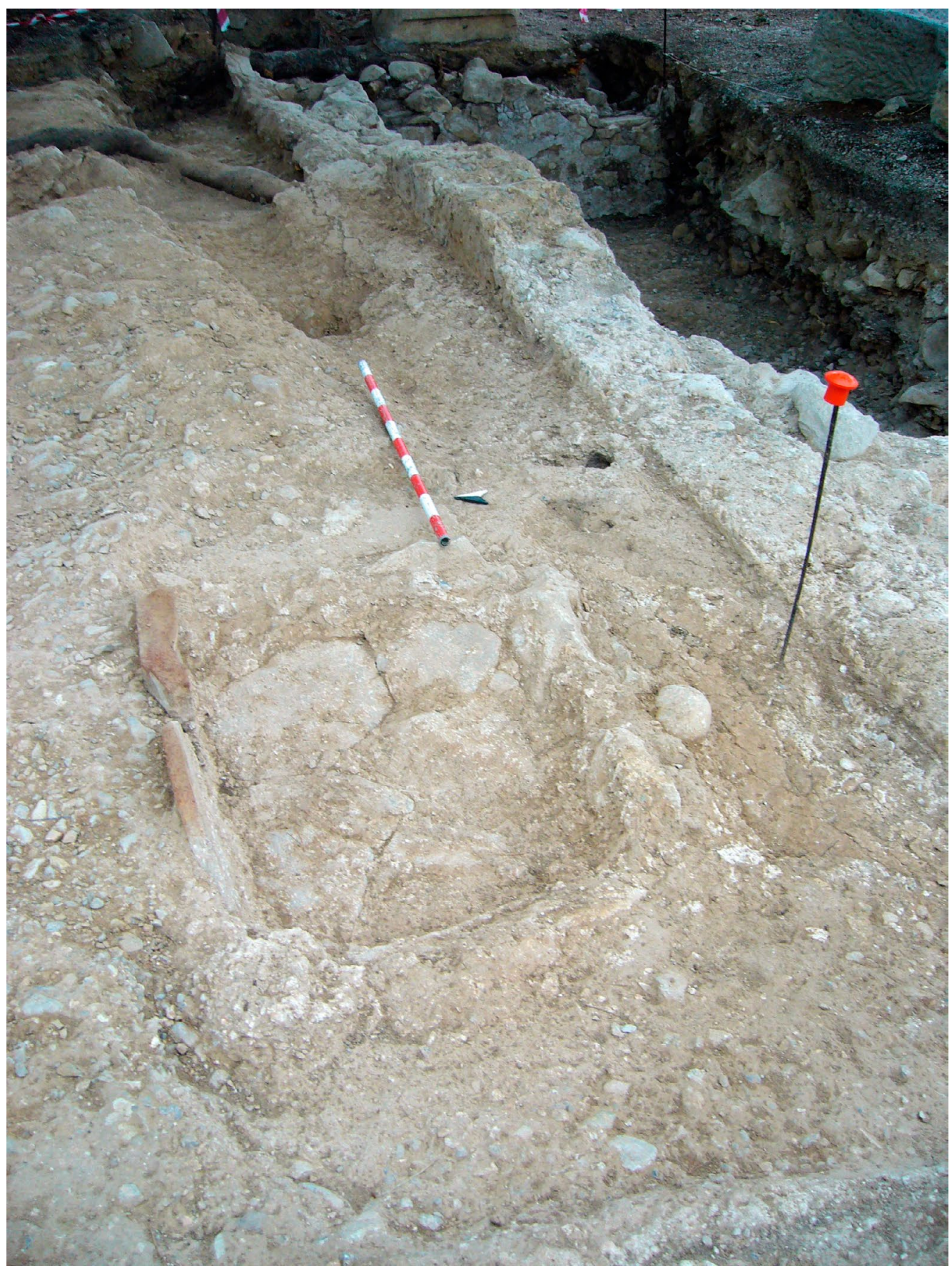

Figura 23: Vista desde el oeste del recinto funerario (MR 213) y cubeta (UE 331).

los esquemas de los modelos funerarios itálicos para monumentos tardorrepublicanos y altoimperiales (Vaquerizo, 2001b, 138).

La existencia de un recinto de delimitación se explica por la ubicación del monumento de la Torre de San Josep lejos del centro urbano y ayudaría a preservar la integridad territorial y legal del sepulcro, como ocurre en otros casos. De esta forma se realzaba su carácter sagrado y se aseguraba su cuidado, ya que la superficie que delimitaba estaría destinada a jardines, a tareas relacionadas con el ritual funerario y al mantenimiento del sepulcro.
Este recinto, aunque sólo parcialmente excavado, parece bastante amplio, como suele ocurrir en los entornos rurales (Ruiz Osuna, 2008, 90). Esto no implica -al menos en nuestra Torre- la existencia de múltiples enterramientos al pie del monumento principal, ya que se limita a una inhumación infantil, como ocurre en el «Camino Viejo de Almodovar» concretamente dentro del Recinto J (Ruiz Osuna, 2008, 159).

Finalmente, la excavación del recinto funerario y del flanco norte y oeste del monumento ha permitido también conocer la cota de circulación romana al exterior de la Torre, que se puede establecer en la 


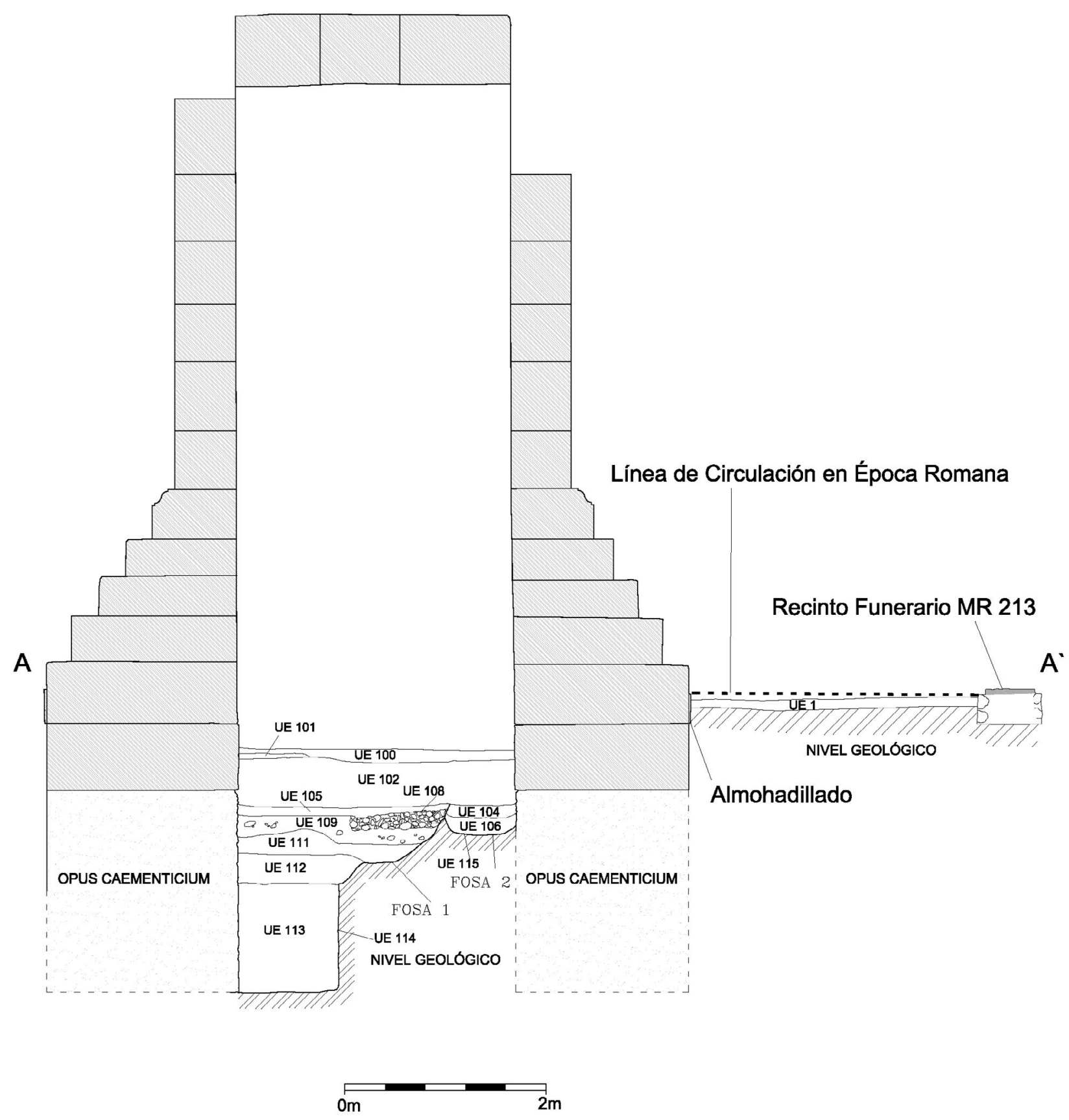

Figura 24: Sección A-A’ (este-oeste) del monumento, cota de circulación de época romana y recinto funerario.

línea superior del almohadillado de la primera grada del edificio. Nos basamos, por un lado, en que los niveles geológicos localizados en la esquina noroeste del monumento, menos sometidos a la erosión que el resto, presentaban una cota superior por encima de la línea inferior de la primera grada. Y por otro lado, en que en un tramo del recinto funerario situado a escasos $3 \mathrm{~m}$ al oeste del monumento se han localizado restos del alzado de la estructura muraria, que marca la línea entre las cimentaciones del muro y el alzado del mismo; y, por tanto, la línea de circulación de época romana, coincidiendo la cota con la línea superior del almohadillado, con una variación de 1 cm (Fig. 24).

Diego Ruiz-Alcalde

Arqueólogo Municipal de Villajoyosa,

Museo Municipal

C/ Barranquet, $\mathrm{n}^{\circ} 14$

03570 Villajoyosa

arqueoleg@villajoyosa.com

Ana María Charquero Ballester

C/ Alonso Cano $n^{\circ} 65,3^{\circ}-\mathrm{F}$

03014 Alicante

anachb@hotmail.com 


\section{BIBLIOGRAFÍA}

AAVV., 1993: La Torre dels Escipions, Monuments a l'abast, Tarragona.

ABAD CASAL, L., 2003: «El tránsito funerario. De las formas y ritos ibéricos a la consolidación de los modelos romanos», en L. ABAD CASAL (Coord.), De Iberia in Hispaniam: la adaptación de las sociedades ibéricas a los modelos romanos, 75-100, Alicante.

ABAD CASAL, L., 2011: «La Torre de Sant Josep», La Vila Joiosa Arqueologia y Museu, Museos Municipales en el MARQ, 198-213 Alicante.

ABAD CASAL, L., ABASCAL PALAZÓN, J.M. y SANZ GAMO, R., 2000: «Monumentos funerarios romanos de época romana en la provincia de Albacete», II Congreso de Historia de Albacete, Tomo I, 271-274, Albacete.

ABAD CASAL, L. y BENDALA GALÁN, M., 1985: «Los sepulcros turriformes de Daimuz y Villajoyosa. Dos monumentos funerarios romanos olvidados», Lucentum, II, 147-184.

ABASCAL, J.M, ALFÖLDI, G. y CEBRIÁN, R., 2011: Segobriga V. Inscripciones romanas 1986-2010, Real Academia de la Historia, Madrid.

ABASCAL, J.M, DIE, R. y CEBRIÁN, R., 2009: Antonio Valcárcel Pio de Saboya, Conde de Lumiares (17481808). Apuntes biográficos y escritos inéditos, Real Academia de la Historia, Alicante.

ADAM, J.P., 1989: La construcción romaine. Materiaux et técniques, Paris.

ALMAGRO BASCH, M., 1951: «El recinto sepulcral romano tardío de El Castellet de Ampurias», AEspA, 24, $\mathrm{n}^{\circ} 83-84,99-116$.

ARANEGUI GASCÓ, C., 1995: «Los monumentos funerarios romanos descubiertos en Edeta (Llíria, Valencia)», Saguntum, 29, 197-210.

ARASA GIL, F., 1987: «El monumento romano de la Ermita de la Virgen del Cid (La Iglesuela del Cid, Teruel)», Boletín del Museo de Zaragoza, 6, 141-180.

AURIGEMMA, S., 1963: I monumento della necropoli romana di Sarsina, Bollettino del Centro di Studi per la Storia dell'Architettura, 13, Roma.

BENDALA GALÁN, M., 2004: «Arquitectura funeraria», en X. DUPRÉ (Ed.), Mérida, Colonia Augusta Emerita, 85-100, Roma.

BELTRÁN FORTES, J., 2002: «La arquitectura funeraria en la Hispania meridional durante los siglos II a.C.-I d.C.», en D. VAQUERIZO (Ed.), Espacios y usos funerarios en el occidente romano, 233-258, Córdoba.

BELTRÁN FORTES, J., MALLER ALLENDE, J., MIRANDA VALDÉS, J., MORENA LÓPEZ, J.A. y RODRÍGUEZ OLIVA, P., 2010: El mausoleo de los Pompeyos de Torreparedones (Baena, Córdoba). Análisis historiográfico y arqueológico. Salsum 1, Monografías del Museo Histórico Municipal de Baen,. Baena.

BELTRÁN FORTES, J., 2010: «Estudio arqueológico de «La Tumba de los Pompeyos», El mausoleo de los Pompeyos de Torreparedones (Baena, Córdoba). Análisis historiográfico y arqueológico. Salsum 1, Monografías del Museo Histórico Municipal de Baena, Baena.
BUILL, F., 2007: Fotogrametría arquitectónica, Aula de Arquitectura, 55, Barcelona.

CANCELA RAMÍREZ DE ARELLANO, P., 2002: «Aspectos monumentales del mundo funerario hispano», en D. VAQUERIZO (Ed.), Espacios y usos funerarios en el occidente romano, 163-180, Córdoba.

CEÁN BERMUDEZ, J.A., 1832: Sumario de las antigüedades romanas que hay en España, Burgos.

CEBRIÁN FERNÁNDEZ, R., 2000: TITULUM FECIT. La producción epigráfica romana en las tierras valencianas, Madrid.

CEBRIÁN FERNÁNDEZ, R., 2010: «La denominada tumba monumental de Segobriga (Saelices, Cuenca). Un mausoleo en forma de altar», Lucentum, XXIX, 139-148.

CID PRIEGO, C., 1947-48: «El monumento conocido por Torre de los Escipiones en las cercanías de Tarragona», Ampurias, 9-10, 137-169.

CID PRIEGO, C., 1949: «El sepulcro de torre mediterráneo y su relación con la tipología monumental», Ampurias, $11,91-126$.

CID PRIEGO, C., 1950: «La torre del Breny, un sepulcro romano en las cercanías de Manresa», Ampurias, 12, 3-53.

DE JUAN, C., CIBECCHINI, F. y VENTO, E., 2011: «El pecio romano Bou Ferrer, un velero de comercio naufragado en la costa de La Vila Joiosa», La Vila Joiosa Arqueologia y Museu, Museos Municipales en el MARQ, 178-198, Alicante.

DÍAZ MARTOS, A., 1960-61: «Los capiteles de orden corintio en Hispania», Ampurias, XXII-XXIII, 223-237.

DÍAZ MARTOS, A., 1985: Los capiteles corintios romanos en Hispania, Madrid.

EISNER, M., 1986: Zur Typologie der Grabbauten im Suburbium Roms, Mainz.

ESCOLANO, G., 1610: Historia general de Valencia, Valencia.

ESCRIVÀ CHOVER, I., 2005: Basas romanas de la Provincia Tarraconensis, Archius i Documents 38, Institució Alfons el Magnànim, Valencia, 98-99.

ESPINOSA RUIZ, A., 2006: «Sobre el nombre de la ciudad ibérica y romana de Villajoyosa y la ubicación del topónimo Alonís/Alonai/Allon», Lucentum, 25, 223-248.

ESPINOSA RUIZ, A., RUIZ ALCALDE, D. y MARCOS GONZÁLEZ, A., 2010: «Villajoyosa romana. De la República a la Antigüedad Tardía. Primera Fase: Torre de Sant Josep», Actuaciones Arqueológicas en la Provincia de Alicante 2008, edición en CD-ROM de la Sección de Arqueología del Ilustre Colegio Oficial de Doctores y Licenciados en Filosofía y Letras y en Ciencias de Alicante, Alicante.

ESPINOSA RUIZ, A., CASTILLO BELINCHÓN, R. y SAEZ LARA, F., 2011: «Una comarca abocada al mar: ports y navegació a la Marina Baixa», La Vila Joiosa Arqueologia y Museu, Museos Municipales en el MARQ, 242-260, Alicante.

FULVIO GIULIANI, C., 1990: L'edilizia nell'antichità, Roma. 
GABELMMAN, H., 1979: Römische Grabbauten der frühen Kaiserzeit, Stuttgart.

GAMER, G., 1981: «La Torre de los Escipiones y otros monumentos funerarios sucesores del Mausoleo de Halicarnaso», Boletín del Seminario de Estudios de Arte y Arqueología, 47, 71-94.

GARCÍA MERINO, C., 1977: «Un sepulcro romano turriforme en la Meseta Norte: el yacimiento arqueológico de Vilde (Soria)», Boletín del Seminario de Estudios de Arte y Arqueología, 43, p. 41-60.

GAWLIKOVSKI, M., 1970: Monuments funéraires de Palmyre, Warszawa.

GISMONDI, A., 1958: Le necropoli, Scavi di Ostia, III, I, Roma.

GONZÁLEZ, M.L., ENCINA PRADA, M. y VIDAL, J.M., 2003: «Un recinto funerario romano en Asturica Augusta (Astorga, León)», Bolskan, 20, 297-308.

GONZÁLEZ VILLAESCUSA, R., 2001: El mundo funerario romano en el País Valenciano. Monumentos funerarios y sepulturas entre los siglo I a.C. y VII d.C., Madrid.

GROS, P., 2001: L'architecture romaine du début du IIlème siècle à la fin du Haut Empire, 2, Maisons, palais, villes et tombeaux, Paris.

GROS, P., 2002: «Les monuments funéraires à édicule sur podium dans l'Italie du Ier siècle av. J.-C», en D. VAQUERIZO (Ed.), Espacios y usos funerarios en el occidente romano, 13-32, Córdoba.

GSELL, ST., 1901: Les monuments antiques de l'Algerie, II, Paris.

GUTIÉRREZ GARCÍA-MORENO, A., 2009: Roman Quarries in the Northeast of Hispania (Modern Catalonia), Tarragona.

HAUSCHILD, Th., 2000: «Villajoyosa (Prov. de Alicante), «Torre de Hércules», en W. TRILLMICH ET ALII, Hispania Antiqua: Denkmäler der Römerzeit, 403, Mainz am Rhein.

HAUSCHILD, Th.; MARINER, S. y NIEMEYER, H., 1966: «Torre de los Escipiones. Ein römischer Grabturm bei Tarragona», $M M, 7,162-188$.

HERAS, F. J., OLMEDO, A., 2010: «Dos nuevos monumentos funerarios en Augusta Emerita. Primer avance de los resultados de la intervención de la calle Almendralejo $n^{\circ} 41$, Mérida (Badajoz, España)», Bolettino di Archeologia On line, Volume speciale.

HERMAN, A., 1964: «Porphyra und Pyramide. Zur Bedeutungsgeschichtlichen überlieferun eines Baugedankes», $J A C h r$.

HERNÁNDEZ VERA, J.A., ARIÑO GIL, E., MARTÍNEZ TORRECILLA, J.M. y NÚÑEZ MARCÉN, J., 1999: «La presa y el ninfeo del Sotillo (Alfaro, La Rioja): un conjunto monumental en la via de Italia in Hispanias», Zephyrus, 52, 239-260.

HESBERG, H., 1993: «Römische Grabbauten in den hispanischen Provinzen», en W. TRILLMICH ET ALII, Hispania Antiqua. Denkmäler der Römerzeit, 159-18, Mainz am Rhein.

JIMÉNEZ SALVADOR, J L., 2002: «Últimas novedades en relación al mundo funerario romano en el este y sureste de Hispania (Siglos II a.C.- IV d.C.)», en D.
VAQUERIZO (Ed.), Espacios y usos funerarios en el occidente romano, 181-202, Córdoba.

KOCKEL, V., 1983: Die Grabbauten vor dem Herculaner Tor in Pompeji, Mainz.

KOVACSOVICS, W., 1983: Römische Grabdenkmaler, Bayern.

LABORDE, A. de, 1806: Voyage pittoresque et historique de l'Espagne, París.

MARCONI, P., 1929: Agrigento, Firenze.

MARCOS GONZÁLEZ, A., 2010: Las Villa romana de El Xarquet, Memoria de Licenciatura, Universidad de Alicante (inédita).

MARTÍ MIQUEL, I., (en preparación): Historia de Villajoyosa. Manuscrito original en Vilamuseu, escrito en 1877 y corregido y ampliado entre 1919 y 1922 por el autor. Transcripción de Francisco Martínez. Edición a cargo de Agustín Galiana, Francisco Martínez y Antonio Espinosa.

MARTÍNEZ VALLE, A., (1995): «El monumento funerario de La Calerilla de Hortunas (Requena, Valencia)», Aespa, 68, 259-283, Madrid.

MUÑOZ, A., GARCIA, I. y PRADOS, F., 2009: «Espacios jerarquizados y áreas funerarias en la necrópolis oriental de Baelo Claudia (Tarifa, Cádiz). Nuevas perspectivas de estudio», en Jorge Bonsor y la recuperación de Baelo Claudia (1917-1921), 57-75, Sevilla.

OLCINA DOMÉNECH, M.H., 2011: «Fondos de Villajoyosa en el Museo Arqueológico Provincial», en La Vila Joiosa Arqueologia y Museu, Museos Municipales en el MARQ, 282-296, Alicante.

POINSSONT, C. y SALOMONSON, J.W., 1963: «Un monument punique inconnu: le masolée d'Henchir Djaouf d'apres les papiers inèdits du Comte C. Borgia», Oudheidkundige Medelingen, 44.

PRADOS MARTÍNEZ, F., 2008: Arquitectura Púnica. Los monumentos funerarios, Anejos de Archivo Español de Arqueología 44, Madrid.

PRADOS MARTÍNEZ, F., 2011: «La necrópolis oriental de Baelo Claudia (Tarifa, Cádiz) en el contexto de la religiosidad Púnico-Mauritana una lectura a partir de las últimas actuaciones arqueológicas», Zephyrus, LXVIII. 191-210

PRADOS, F. y GARCIA, I., 2010: «Nuevas actuaciones arqueológicas en la necrópolis hispanorromana de Baelo Claudia (Tarifa, Cádiz), balance de la campaña de 2009 y perspectivas», Aljaranda, 77, 4-12.

RAKOB, F., 1979: «Numidische Königsarchitektur in Nordafrika», en H. G. HORN, y Ch. B. RUGER, Die Numider, Bonn.

RAMIREZ DE ARELLANO, Ma L., 2002: «Aspectos monumentales del mundo funerario hispano», en D. VAQUERIZO (Ed.), Espacios y usos funerarios en el occidente romano, 163-180, Córdoba.

REMOLÀ, J. A. y ACERO, J., 2011: La gestión de los residuos urbanos en Hispania: Xavier Dupré Raventós (1956-2006), In Memoriam, Anejos de Archivo Español de Arqueología LX, Mérida.

RODRIGUEZ HIDALGO, J. M., 1979-80: «Anotaciones en torno a Basilippo. La Torre del Cincho», Habis, 10-11. 
ROMANELLI, P., 1970: Topografia e archeologia dell' Africa romana, Torino.

RUIZ ALCALDE, D., 2010: Las Termas Públicas del Municipium romano de Villajoyosa, Memoria de Licenciatura, Universidad de Alicante (inédita).

RUIZ OSUNA, A., 2005: «La vía sepulchralis occidental: un ejemplo de monumentalización funeraria en Colonia Patricia», Anales de Arqueologia Cordobesa, 16, 79-104.

RUIZ OSUNA, A., 2008: Topografia y monumentalización funeraria en Baetica: Conventus Cordubensis y Astigitanus, Monografías de la Arqueología Cordobesa, Córdoba.

RUIZ OSUNA, A., 2010: Colonia Patricia, centro difusor de modelos: Topografia y monumentalización funerarias en Betica, Córdoba.

SANMARTÍ, J., 1984: «Els edificis sepulcrals dels Països Catalans, Aragó i Múrcia», Fonaments, 4, 87-160.

STUCHI, S., 1975: Archittetura cirenaica, Roma.

TORELLI, M., 1968: «Monumenti funerari romani con fregio dorico», Dialoghi di Archeologia, 1, 32-54.

VALCÁRCEL, A., de, sf.: Inscripciones y Antigüedades del Reyno de Valencia, Memorias de la Real Academia de la Historia, Madrid.
VAQUERIZO, D., ed. 2001: Funus cordubensium. Costumbres funerarias en la Córdoba romana, Córdoba.

VAQUERIZO, D., 2001b: «Formas arquitectónicas funerarias de carácter monumental en Colonia Patricia Corduba», AEspA, 74, 131-160.

VAQUERIZO, D., ed. 2002: Espacios y usos funerarios en el occidente del imperio, Actas del Congreso Internacional celebrado en la Facultad de Filosofía y Letras de la Universidad de Córdoba, Córdoba.

VAQUERIZO, D., 2002b: «Recintos y acotados funerarios en Colonia Patricia Corduba», Madrider Mitteilungen, 43, 168-206.

VAQUERIZO, D., 2010: Necrópolis urbanas en Baetica. Documenta 15, Institut Català d'Arqueologia Clàssica. Tarragona.

VARELA BOTELLA, S., 2000: «Actuaciones arqueológicas en dos monumentos de la Antigüedad: Villajoyosa y Rojales», Scripta in Honorem, Homenaje a Enrique Llobregat, II, 295-301, Alicante.

WILL, E., 1949: «La tour funeraire de Palmyre». Syria, 26. ZAHN, E., 1982: Die Igeler Säule in Igel bei Trier. Trier.

ZUGMEYER, S. Y BADIE, A., 2012: "Comprendre l'usage de la pince à crochet, un enjeu pour restituer l'organisation des chantiers antiques». Anejos de Archivo Español de Arqueología LXIV, 107-115.

Recepción: 26-09-2013

Aceptación: 08-01-2014 